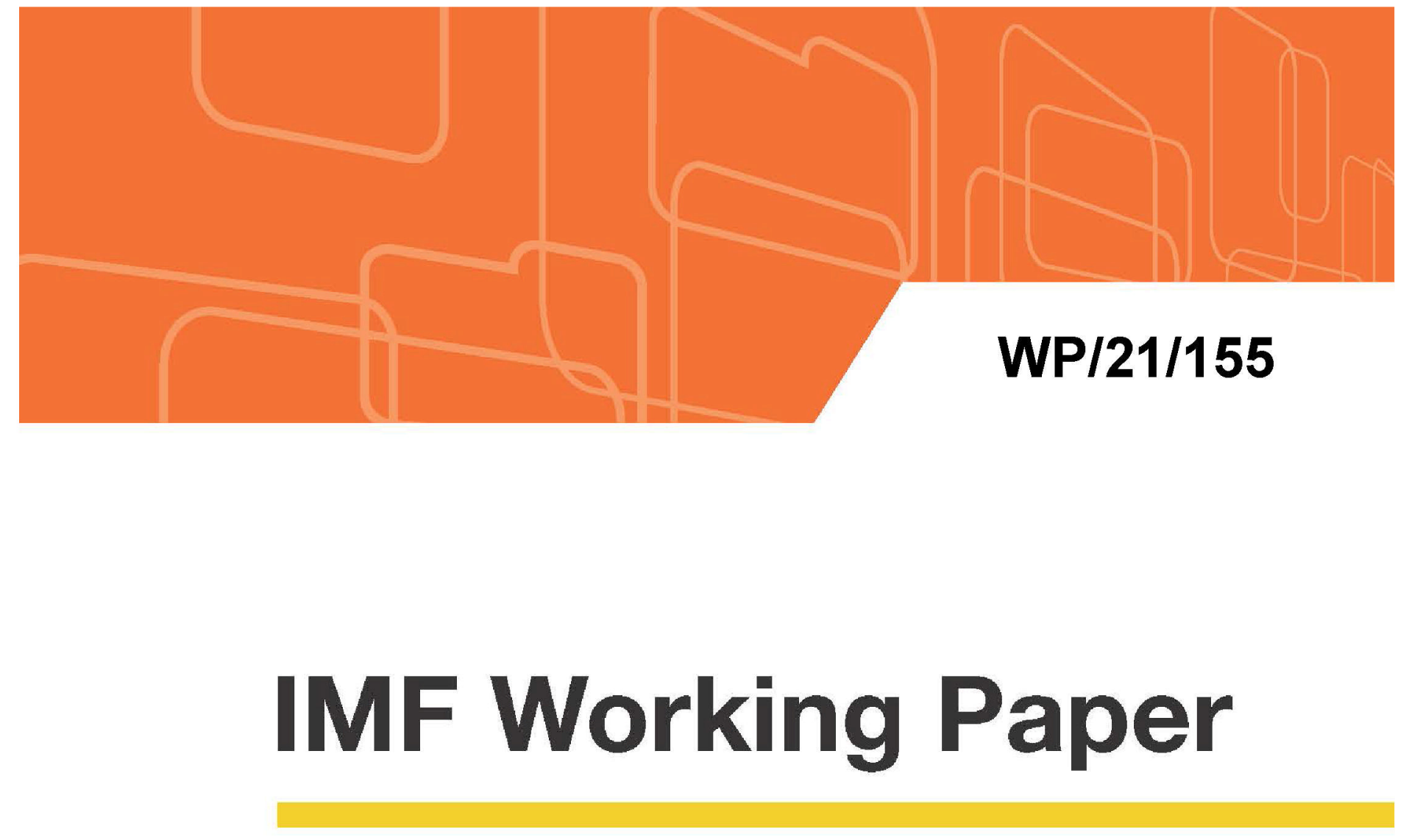

\title{
The Long-Run Impact of Sovereign Yields on Corporate Yields in Emerging Markets
}

by Delong Li, Nicolas E. Magud, Alejandro Werner, Samantha Witte

IMF Working Papers describe research in progress by the author(s) and are published to elicit comments and to encourage debate. The views expressed in IMF Working Papers are those of the author(s) and do not necessarily represent the views of the IMF, its Executive Board, or IMF management. 


\title{
IMF Working Paper
}

\author{
Western Hemisphere Dept
}

\section{The Long-Run Impact of Sovereign Yields on Corporate Yields in Emerging Markets}

\author{
Delong Li, Nicolas E. Magud, Alejandro Werner, Samantha Witte ${ }^{1}$ \\ Authorized for distribution by Alejandro Werner
}

\begin{abstract}
We analyze the long-run impact of emerging-market sovereign bond yields on corporate bond yields, finding that the average pass-through is around one. The pass-through is larger in countries with greater sovereign risks and where sovereign bonds are more liquid. It is also greater for corporate bonds with lower ratings, shorter maturities, and for those issued by financial companies and government-related firms. Our results support theoretical arguments that corporate and sovereign yields are linked together through credit risks and liquidity premiums. Consequently, high sovereign risks may slowdown growth by persistently increasing private sector borrowing costs.
\end{abstract}

JEL Classification Numbers: F34, G12, G15.

Keywords: bonds; emerging markets; sovereign risks; transfer risks; liquidity premium.

Author's E-Mail Address: delong@uoguelph.ca; nmagud@imf.org; awerner@imf.org; samantha.witte@worc.ox.ac.uk.

\footnotetext{
${ }^{1}$ Delong Li, Department of Economics and Finance, Gordon S. Lang School of Business and Economics, University of Guelph; Nicolas E. Magud, Institute for Capacity Development, International Monetary Fund (IMF); Alejandro Werner, Western Hemisphere Department, International Monetary Fund; and Samantha Witte, Department of Economics, University of Oxford. We thank Jan Ditzen for his comments on numerical estimation. We thank Mitchell Riddell and Ana Maria Trujillo for their excellent research assistance. We thank IHS Markit for offering us the valuable data. Li thanks Social Sciences and Humanities Research Council for financial support. The views expressed in this paper are those of the authors and do not necessarily represent the views of the IMF, its Executive Board, or IMF management.
} 


\section{Introduction}

Typically, sovereign risks are highly persistent and so are sovereign bond yields (see, e.g., Reinhart and Rogoff 2004). But would a country's corporate bond yields move, persistently, in tandem with its sovereign yields? In other words, is there a stable long-run relation, such as a cointegrating relation, between corporate and sovereign yields of the same country? We find that, in emerging markets, the answer is yes. ${ }^{2}$ Moreover, on average, there is almost full pass-through from sovereign to corporate yields. The strength of this pass-through is conditional on countryand bond-specific characteristics, such as risk levels, maturities, bid-ask yield spreads, issuers' industry groups, and government relations. Importantly, these findings provide empirical evidence to support existing theoretical models' assumptions and predictions that, to the best of our knowledge, had not been provided before (see, among others, Mendoza and Yue 2012; Corsetti, Kuester, Meier, and Müller 2014).

Our findings also relate, though indirectly, to the discussion of the externality of an emerging market's fiscal balance on long-term growth. If there is a positive, strong, and persistent passthrough from sovereign bond yields to corporate bond yields, then weaker fiscal positions might slowdown growth by increasing borrowing costs, thus reducing private sector investment for an extended period of time; and vice versa.

Why are the corporate and sovereign bond yields of a country closely related in the long run? The most straightforward reason is that they might be driven by common economic factors such

\footnotetext{
${ }^{2}$ By using the expression "long-run relation", we refer to a persistent association between corporate and sovereign bond yields. It should be emphasized that this persistence does not mean that the impact of sovereign yields on corporate bond pricing will last for a long period of time in the common macroeconomic sense, which could be years. In contrast, because bond prices react to information much faster than macroeconomic variables, we aim to investigate persistence in a horizon of several weeks or months in the sense of Dittmar and Yuan (2008) - see section 3.1 for more discussions.
} 
as macroeconomic fundamentals, capital flows, commodity prices, and global financial conditions. Moreover, the theoretical literature has documented two additional channels in which sovereign yields can have persistent causal effects on corporate yields. First, sovereigns can transfer credit risks to domestic firms - often referred to as the "transfer-risk channel." During periods of sovereign distress, governments could divert resources from the private sector to cover their fiscal needs, for example, by raising taxes (Corsetti, Kuester, Meier, and Müller 2014); high sovereign risks may further erode the value of government guarantees; and can also disrupt financial intermediation by impairing the balance-sheets of banks that hold government debt; and vice versa (Acharya, Drechsler, and Schnabl 2014; Gennaioli, Martin, and Rossi 2013; Bocola 2016). Consistent with this notion, Mendoza and Yue $(2011 ; 2012)$ argue that corporate bond yields contain a sovereign risk component, leading to an arbitrage relation between sovereign bonds and corporate bonds of the same country, so that their yields are linked together in the long run. ${ }^{3}$

Second, sovereign bonds can affect corporate bond pricing further through a "liquiditypremium channel" (Yuan 2005; Dittmar and Yuan 2008). This mechanism is particularly important in emerging economies, where bond markets are less complete, and illiquidity tends to be persistent. ${ }^{4}$ Specifically, sovereign bonds can act as benchmark securities and hedging instruments, because their yields provide investors with information about the country's systemic

\footnotetext{
${ }^{3}$ Another application of this theoretical notion, though not the focus of our paper, is that sovereign bond yields usually represent a floor for corporate bond yields or, in terms of bond prices or credit ratings, a ceiling, known as the "sovereign-ceiling hypothesis." Recent studies include, among others, Borensztein, Cowan, and Valenzuela (2013), Adelino and Ferreira (2016), and Almeida, Cunha, Ferreira, and Restrepo (2017).

${ }^{4}$ Bekaert, Harvey, and Lundblad (2007) document the persistence of illiquidity in emerging equity markets. Given that corporate bonds are mostly traded over the counter, the illiquidity is further influenced by dealers' search and order-processing costs that are likely to be persistent as well. We thus expect the persistence of illiquidity in emerging bond markets to be even stronger than that in emerging equity markets.
} 
risks. ${ }^{5}$ This effect improves the liquidity of corporate bonds and decreases their yields by lowering liquidity premiums. Moreover, the effect becomes weaker when sovereign bonds are less liquid themselves, seeing that investors are reluctant to use illiquid bonds as benchmarks or for hedging purposes. Consequently, sovereign bond liquidity influences both sovereign bond yields and corporate bond yields, and therefore, corporate and sovereign bond yields are closely related.

We estimate the long-run impact of sovereign yields on corporate yields, in levels, using a novel and comprehensive dataset. ${ }^{6}$ Our sample consists of 2,045 corporate bonds issued by 1,040 companies, and 431 sovereign bonds, from 46 emerging economies (all denominated in U.S. dollars). The results show evidence supporting both the transfer-risk and the liquidity-premium channels. In contrast, previous empirical studies largely focus on short-run associations between changes of corporate and sovereign borrowing costs. The existing literature also has smaller samples, usually covering less than 200-300 emerging-market firms, and almost exclusively discuss the transfer-risk channel but are silent on the liquidity-premium channel (e.g., Bedendo and Colla 2015; Durbin and Ng 2005).

We find that, on average, the long-run pass-through from sovereign yields to corporate yields is around one and highly significant. Our estimation relies on the cross-sectional augmented distributed-lag (CS-DL) approach developed in Chudik, Mohaddes, Pesaran, and Raissi (2013; 2016). A key advantage of this method is that it can account for unobserved common economic

\footnotetext{
${ }^{5}$ The systemic risks may include both the country's macroeconomic risks and sovereign transfer risks.

${ }^{6}$ We define the long-run level relation rigorously in equation (3) in section 3.2. In short, given that bond yields typically contain unit roots (see, for instance, Neal, Rolph, Dupoyet, and Jiang 2015 and references therein), the longrun relation we refer to is essentially a cointegrating relation. Accordingly, we conduct three commonly adopted paneldata cointegration tests toward our sample: the modified Phillips-Perron test, the modified Dickey-Fuller test, and the Dickey-Fuller test, developed in Pedroni $(1999,2004)$ and Kao (1999), finding that the weekly data of corporate and sovereign yields of the same country are strongly cointegrated. See Appendix A1 for details. Moreover, we discuss in section 2 why we choose to study bond yields rather than credit spreads. We further show in section 4.2 that the estimation results obtained from bond yields are similar to the results obtained from bond spreads.
} 
factors that may simultaneously drive corporate and sovereign bond yields, thus helping isolate causal effects. Our analysis also includes control variables at bond-, country-, and global-levels that are common in previous empirical studies to further mitigate the concern for omitted variables. $^{7}$

Furthermore, through subsample analysis, we examine the transfer-risk channel and the liquidity-premium channel, finding evidence that they co-exist. The transfer-risk channel predicts that the pass-through from sovereign to corporate yields is stronger in countries with greater sovereign risks-where governments are more likely to transfer risks to domestic firms. Our results support this prediction by showing that the estimated pass-through is larger in countries with lower sovereign credit ratings and in those with higher public external debt (relative to foreign reserves). Moreover, because government-related firms (regardless of their industry groups) and banks holding government debt as part of their assets are more exposed to transfer risks, we expect their bond yields to be more sensitive to sovereign yields. Our results support this prediction to a large extent except that, in our findings, government-related banks are more resilient to sovereign risk transmission than banks without government relations. The latter result is in contrast to the notion of "moral suasion" but consistent with earlier works in Acharya, Eisert, Eufinger, and Hirsch (2018) towards European advanced economies.

On the other hand, the liquidity-premium channel predicts that the bond yield association between corporates and sovereigns is weaker if sovereign bonds are less liquid. To examine this prediction, we double-sort our sample based on sovereign bonds' credit ratings and bid-ask yield spreads, as lower-rated sovereign bonds are naturally less liquid. We find that the sensitivity of

\footnotetext{
${ }^{7}$ In addition to the omitted variable issue, we further discuss potential reverse causality and how our method is robust to it in sections 3.2 and 4.2 .
} 
corporate yields to sovereign yields is indeed smaller in countries where sovereign bid-ask spreads are wider, i.e., where sovereign bonds are less liquid; moreover, this holds true regardless of the country's credit rating. This result supports the liquidity-premium explanation. Furthermore, conditional on either high or low sovereign bid-ask spreads, the pass-through is always stronger in countries where sovereign credit ratings are lower, confirming the transfer-risk mechanism once again. Therefore, both channels exist and contribute to the observed corporate-sovereign nexus.

Lastly, we find that the sensitivity of corporate yields to sovereign yields also relies on corporate bonds' credit ratings and maturities. The sensitivity is particularly strong (in fact, larger than one) for corporate bonds with non-investment-grade ratings, but is about halved for investment-grade corporate bonds. The results are in line with the usual theoretical notion that default premiums are convex in default risks - thus, corporate bonds that are riskier themselves are more vulnerable to transfer risks. Moreover, the sensitivity is strongest for corporate bonds with maturities between 1 to 5 years (around one), about 15 percent lower for those whose maturities are between 5 to 10 years, and almost 50 percent lower if maturities are longer than 10 years. The results imply that corporate bond investors care less about transfer risks as time horizons increase. ${ }^{8}$ Conceptually, even though governments can transfer their current credit risks to private sectors, it is difficult for the transfer effects to remain as strong for more than 5 or 10 years.

The paper is organized as follows. Section 2 reviews the existing literature. In section 3, we discuss data and methodology. Section 4 presents main results. Section 5 includes subsample analysis to examine the transfer-risk and liquidity-premium channels, and in section 6 , we analyze

\footnotetext{
${ }^{8}$ The fact that transfer risks matter most in time horizons between 1 and 5 years is in line with Arteta and Hale (2008), who find that the negative impact of sovereign debt crisis on credit availability of emerging-market firms persists for two years. Moreover, this result does not contradict the notion that transfer risks can cause a "long-run" association between corporate and sovereign bond yields. Bond yields react to information relatively fast, and thus, the time horizon between 1 and 5 years is a sufficiently "long-run" period in bond markets.
} 
ratings, maturities, and whether the corporate-sovereign relation is nonlinear (following Bevilaqua, Hale, and Tallman 2020). Section 7 concludes the paper.

\section{Related Literature}

An extensive amount of theoretical literature has discussed the linkage between sovereign and private sector borrowing costs, and our paper provides empirical support to this literature. To the best of our knowledge, such support has not been provided yet. In some of the existing models, the corporate--sovereign relation is adopted as an assumption. Corsetti, Kuester, Meier, and Müller (2014) assume that there exists a steady-state relation between private sector credit spreads and sovereign risks; Mendoza and Yue $(2011 ; 2012)$ assume that there is an arbitrage relation between sovereign bonds and domestic firms' working capital loans, because their default risks are positively related; see also Neumeyer and Perri (2005) and Uribe and Yue (2006). In some other models, the relation between corporate and sovereign credit risks (and borrowing costs) is derived as a conclusion. Bocola (2016) introduces a model in which sovereigns can transfer credit risks to the private sector through banks' holding of government debt. Sosa-Padilla (2018) jointly models this transfer-risk mechanism and endogenous sovereign defaults. Acharya, Drechsler, and Schnabl (2014) model a loop between sovereign and bank credit risks: a distressed banking sector induces government bailouts, which increases sovereign credit risks, and the increased sovereign risks in turn weaken the banking sector by eroding the value of government guarantees and bond holdings; see also Cooper and Nikolov (2018) and Farhi and Tirole (2018).

Empirically, this article differs from previous papers in several ways. We examine bond yields, in contrast to earlier works that focus on credit default swap (CDS) premiums or credit spreads. We opt not to study CDS first because it is difficult to obtain data for a large sample of emergingmarket firms. In the literature that uses CDS data, the underlying firms are often from advanced 
economies and the samples are relatively small compared to ours: e.g., there are 200 firms in Harjes (2011), 36 banks in Acharya, Drechsler, and Schnabl (2014), 118 firms in Bedendo and Colla (2015), 226 firms in Augustin, Boustanifar, Breckenfelder, and Schnitzler (2018), and 54 banks in Li and Zinna (2018). Bai and Wei (2012) consider more than 2,000 firms in 30 different countries, but only 267 firms are from emerging economies. Furthermore, the CDS premium is a measure of credit risks and, thus, can shed little light on the liquidity-premium channel.

Furthermore, we study bond yields rather than credit spreads over risk-free rates because individual bond spreads are not directly observable in the data. Instead, one needs to numerically estimate credit spreads by fitting zero-coupon corporate yield curves; see, e.g., Durbin and $\mathrm{Ng}$ (2005) and Peter and Grandes (2005). This not only limits the sample to including only firms with multiple bond issuances that are enough for estimating the yield curves, but also inevitably introduces measurement error in the resulting credit spreads that will bias the estimation results. Therefore, we study bond yields and include risk-free rates (proxied by U.S. Treasury yields) as a control variable to mitigate the concern that risk-free rates can simultaneously influence corporate and sovereign yields. We also show that our results are robust to replacing bond yields with credit spreads in section 4.2. Other related works that explore credit spreads include: Cavallo and Valenzuela (2009) and Zinna (2014) who use aggregate data of EMBI (Emerging Markets Bond Index) and CEMBI (Corporate Emerging Markets Bond Index) spreads; Neri (2013); Zoli (2013); and Albertazzi, Ropele, Sene, and Signoretti (2014) that study the linkage between sovereign spreads and banks' lending rates in advanced economies in Europe.

An important recent paper that also explores the bond yield association between corporates and sovereigns is Bevilaqua, Hale, and Tallman (2020). A major difference from our work is that 
they focus on primary corporate bond yields at issuance, while we study secondary market yields. ${ }^{9}$ Moreover, their sample includes all local-currency denominated bonds. Our sample, on the contrary, given our interest in emerging economies, consists of all U.S.-dollar denominated bonds. This is because expected domestic currency deprecation can cause a strong co-movement of sovereign and corporate yields for bonds in local currencies, but such expected depreciation is difficult to measure empirically. In addition, Bevilaqua, Hale, and Tallman (2020) document that the association between primary corporate bond yields and sovereign yields weakens when sovereign yields are sufficiently high. We discuss this potential nonlinearity in section 6.2.

Our paper also differs from all the above-mentioned empirical works because we aim to analyze the long-run association. To the best of our knowledge, Dittmar and Yuan (2008) is the only empirical paper that has discussed this relation before us. Their sample consists of data of credit spreads of 98 sovereign bonds and 239 corporate bonds in 8 emerging economies. They estimate a vector autoregression for each country separately and characterize the long-run impact of sovereign spreads on corporate spreads through cumulative impulse response functions. We instead consider a much larger sample and study bond yields to avoid biases caused by measurement error in credit spreads. Additionally, we estimate the model at the bond-level and allow the impact of sovereign yields on corporate yields to differ across bonds even in the same country. This helps distinguish the transfer-risk channel and the liquidity-premium channel, also shedding light on which types of corporate bonds are most vulnerable to sovereign risks.

\footnotetext{
${ }^{9}$ Other papers that study primary issuances of corporate bonds (or syndicated loans) and their relations to sovereign risks include Eichengreen and Mody (2000); Dailami (2010); and Ağca and Celasun (2012).
} 


\section{Data and Methodologies}

\subsection{Data}

The data of corporate bonds are obtained from I Markit. It includes weekly data of individual bonds' bid-, ask-, and mid-yields to maturity, maturity dates, issuers, and many other important bond-level features (such as whether the bonds are defaulted, perpetual, inflation-adjusted, government-related, etc.) between March 2016 and April 2019 (160 weeks in total). ${ }^{10}$ Unlike stocks, most corporate bonds are not traded every day or even every week. An advantage of the Markit dataset is that it can provide fair bond valuations, based on multiple sources of market information such as direct dealer quotes, even on days when there are no transactions (Schestag, Schuster, and Uhrig-Homburg 2016). Moreover, even though our sample period is shorter than many macroeconomic studies that examine long-run relations between aggregate variables, it is sufficient to estimate the association between corporate and sovereign bond yields. This is because asset prices react to information much more rapidly than most macroeconomic variables. In a related paper, Dittmar and Yuan (2008) study eight emerging economies, finding that the long-run impact of sovereign credit spreads on corporate credit spreads plateau after a period of about 50 to 100 days.

We link the Markit data on bond pricing to Bloomberg and Datastream through each bond's international security identification numbers (ISIN) to obtain additional bond-level characteristics, including country of risk, classification description, industry group, issue currency, credit ratings, and issuers' financial data. Country of risk is used to identify the nationality of a bond, as defined

\footnotetext{
${ }^{10}$ IHS Markit introduced this data in 2016. Earlier data are not available to us and are in an inconsistent format, where bond valuations are based less on dealer quotes but more on matrix pricing techniques. Moreover, even though daily data are available during this sample period, we follow Acharya, Drechsler, and Schnabl (2014) to work with weekly data to mitigate the concern about measurement error that may be caused by lack of liquidity or noisy trading.
} 
by Bloomberg. ${ }^{11}$ We keep only bonds whose country of risk is deemed as an emerging economy, as per the IMF World Economic Outlook definition. The Bloomberg variable classification description is to identify bonds that are guaranteed, owned, or sponsored by governments. We use the Bloomberg variable industry group to obtain the business industries of issuing companies. We keep only corporate bonds denominated in U.S. dollars, as identified by the issue currency from Bloomberg. ${ }^{12}$ Bond credit ratings by Standard \& Poor's, Moody's, and Fitch are downloaded from Bloomberg at quarterly frequency, and each rating is assigned to a numeric value from 1 (AAA) to 22 (defaulted) - that is, we assume a linear relation following Acharya, Drechsler, and Schnabl (2014). ${ }^{13}$ We further collect quarterly financial data of issuers including profit margin, leverage, asset tangibility, and interest coverage from Datastream, but such data are available for only a small fraction (17 percent) of our sample. ${ }^{14}$ Lastly, for each country that we have corporate bond

\footnotetext{
${ }^{11}$ This approach is based on a 10-point methodology taking into account the issuing company's country of domicile ( 4 points), country of listing ( 3 points), country of largest revenue ( 2 points), and reporting currency ( 1 point). The country with the highest points is defined as the country of risk, and any scoring ties go to the country of domicile. For example, suppose that a bond issuer's country of domicile is Mexico; its country of listing is U.S.; the company receives its largest revenue also from Mexico; and the bond is denominated in U.S. dollars. Then, the total points would be $4+2=6$ for Mexico, and 3+1=4 for U.S. Consequently, the country of risk would be assigned as Mexico. Red-chip issuers and holding companies are treated differently. See the official documents provided by Bloomberg L.P. for more details.

${ }^{12} \mathrm{We}$ choose not to study bonds denominated in local currencies because their yields are highly influenced by the expected depreciation of local exchange rates that is difficult to measure empirically.

${ }^{13}$ For each of the three rating agencies, we use their long-term ratings if available. Only when long-term ratings are unavailable, do we use short-term ratings. If short-term ratings are also missing, we treat the bond as unrated by the corresponding rating agency. We match weekly bond yields with the most recent quarterly ratings.

${ }^{14}$ Profit margin is the ratio between net income and total revenue. Leverage is the ratio between book debt and total assets. Asset tangibility is the ratio between property, plants, and equipment (net) and total assets. Interest coverage ratio equals earnings before interests and taxes divided by interest expenses. We match weekly bond yields with the most recent quarterly financial data.
} 
data, we collect weekly data of all individual sovereign bonds with non-missing data from Bloomberg in the same format. ${ }^{15}$

We further implement the following data-cleaning procedure: (1) drop bonds that are defaulted, perpetual, or inflation-adjusted; (2) drop bonds with maturity less than a year; (3) trim the sample at the top and bottom 0.5 percent by mid-yields and bid-ask yield spreads, and drop observations with non-positive yields; ${ }^{16}$ (4) drop bonds with less than 30 weeks of consecutive data in the sample (Chudik, Mohaddes, Pesaran, and Raissi 2017); ${ }^{17}$ (5) drop duplicated bonds issued under Rule 144A, if its Regulation-S counterpart is already in the sample.

These steps lead to a final sample of 2,045 U.S.-dollar corporate bonds, issued by 1,040 companies, and 431 U.S.-dollar sovereign bonds, from 46 emerging economies. ${ }^{18}$ The number of bonds in each country is shown in Appendix A2. In addition, to construct control variables, we collect data of country-level stock-market indices from Morgan Stanley Capital International (MSCI) and S\&P500 index through Bloomberg; US Treasury yields from FRED; each country's nominal U.S. dollar exchange rate, real effective exchange rate, real GDP growth, CPI growth, current account balance, real GDP per capita, public external debt, and foreign reserves from IMF internal databases. The summary statistics for key variables are shown in Table 1.

\footnotetext{
${ }^{15}$ We collect sovereign bond data from Bloomberg because the Markit database covers only a limited amount of sovereign bonds. The pricing source at Bloomberg is the Evaluated Pricing Service (BVAL). The sovereign ratings are the long-term foreign currency issuer/debt ratings by Standard \& Poor's, Moody's, and Fitch, if available.

${ }^{16}$ The bid-ask yield spread is the difference between the bid-yield and the ask-yield.

${ }^{17}$ Before doing so, we fill the gaps in the time series data by linear interpolation, which accounts for around 5.9 percent of the sample.

${ }^{18}$ The selection of countries is data-driven in the sense that to be included in our sample, a country needs to have at least one U.S.-dollar corporate bond and one U.S.-dollar sovereign bond surviving our data-cleaning process. We consider emerging economies only and U.S.-dollar bonds only to increase comparability across countries and also to mitigate the concern about exchange rate movements affecting bond yields. That said, we admit that our conclusions may better apply to emerging economies as a whole, and to countries where U.S.-dollar bonds play an important role in corporate and government financing, compared to countries where the role of U.S.-dollar bonds is marginal.
} 


\subsection{Empirical models}

Our first step is to pair corporate bonds with sovereign bonds. A seemingly natural way is to match bonds with similar features, such as maturities. Durbin and Ng (2005) apply this matching strategy to study the "sovereign ceiling hypothesis" on whether a country's corporate bonds must trade at higher credit spreads than its government bonds. In their empirical design, finding the most closely matched bonds in maturities is crucial because they aim to compare the magnitudes of bond spreads. Maturity mismatch can lead to biases in this comparison due to term premia and expected inflation. In contrast, we aim at characterizing the time-series association between corporate and sovereign yields. Theoretically, this association does not rely exclusively on corporate bonds and sovereign bonds having similar maturities. For example, in the transfer-risk channel, if the government imposes higher taxes in periods of fiscal distress, all domestic firms will be affected, and their bond yields will increase with sovereign yields, ceteris paribus, regardless of maturities. Therefore, we follow Dittmar and Yuan (2008) to pair each corporate bond with an equal-weighted portfolio of all available sovereign bonds of the same country. ${ }^{19}$

We study individual corporate bonds, because the impact of sovereign yields on corporate yields may differ across corporate bonds. To account for this possibility, we allow each corporate bond to have its own sensitivity to sovereign yields and report the cross-sectional average sensitivity, referred to as the mean-group estimates. Pesaran and Smith (1995) and Pesaran, Shin, and Smith (1999) have shown that in this heterogeneous-panel setup, traditional estimators based

\footnotetext{
${ }^{19}$ Furthermore, we find that if we match each corporate bond and its home-country sovereign bond with the closest maturity (or further with the closest maturity, ratings, and bid-ask yield spreads simultaneously) through minimizing the mean-absolute distance or mean-squared distance, the estimated sovereign-to-corporate pass-through is still highly significant, but the magnitude is smaller; see section 4.2.
} 
on ordinary least squares (OLS) or generalized method of moments (GMM) are inconsistent, because they require the slope coefficients to be homogeneous across panel individuals.

We introduce our model and notations as follows. Suppose that corporate bond $I$ is from country $j$, and use $y_{i, j, t}$ to denote its yield on date $t$. We pair this observation with $x_{j, t}$ that represents the average yield on the sovereign portfolio of country $j$ on the same date. Since for any given corporate bond, its nationality is uniquely determined by the country of risk, we can convert the three-dimensional panel to a two-dimensional panel based on $y_{i, t}$ and $x_{i, t}$. We use $y_{i, t}$ as the dependent variable and $x_{i, t}$ as the independent variable, and follow Chudik, Mohaddes, Pesaran, and Raissi $(2013 ; 2016)$ to set up a conditional auto-regressive distributed lag (ARDL) panel-data model with unobserved common factors $\boldsymbol{f}_{t}$ that may simultaneously influence $y_{i, t}$ and $x_{i, t} \cdot{ }^{20}$

$$
\begin{gathered}
y_{i, t}=\sum_{l=1}^{p_{y i}} \varphi_{i l} y_{i, t-l}+\sum_{l=0}^{p_{x i}} \beta_{i l} x_{i, t-l}+u_{i, t}, \\
u_{i, t}=\boldsymbol{\gamma}_{i}^{\prime} \boldsymbol{f}_{t}+\varepsilon_{i, t},
\end{gathered}
$$

for $i=1, \ldots, N$ and $t=1, \ldots, T$, where $p_{y i}$ and $p_{x i}$ are the lag orders chosen to be sufficiently large so that $u_{i, t}$ is serially uncorrelated across all $I$; and $\varphi_{i l}$ and $\beta_{i l}$ are bond-specific short-run coefficients. The corresponding long-run impact of $x_{i, t}$ on $y_{i, t}$ is characterized by

$$
\theta_{i}=\frac{\sum_{l=0}^{p_{x i}} \beta_{i l}}{1-\sum_{l=1}^{p_{y i}} \varphi_{i l}},
$$

which is interpreted as the derivative of $y_{i, t}$ with respect to $x_{i, t}$ conditional on $y_{i, t}=y_{i, t-1}=\cdots=$ $y_{i, t-p_{y i}}, x_{i, t}=x_{i, t-1}=\cdots=x_{i, t-p_{x i}}$, and $u_{i, t}=0$. When $y_{i, t}$ and $x_{i, t}$ are unit-rooted, $\theta_{i}$ is the

\footnotetext{
${ }^{20}$ This conditional ARDL model is derived from a vector autoregressive (VAR) model of $\boldsymbol{z}_{i, t}=\left(y_{i, t}, x_{i, t}\right)^{\prime}$; see Chudik, Mohaddes, Pesaran, and Raissi $(2013 ; 2016)$ for technical details. Equation (1) can also include bond-specific constants (i.e., fixed effects) and bond-specific deterministic trends. We omit them here for notation convenience.
} 
cointegrating coefficient, and when they are stationary, $\theta_{i}$ is the long-run impact of a permanent change in the mean of $x_{i, t}$ on $y_{i, t}$.

There exist, broadly speaking, two ways to estimate the bond-specific long-run pass-through $\theta_{i}$. One way is by estimating equations (1) and (2) for each corporate bond $I$ to obtain the estimates of short-run coefficients and calculating $\theta_{i}$ by equation (3). This method is referred to as the ARDL approach. An alternative is to rewrite the ARDL model into a distributed lag (DL) form, in which the long-run parameter $\theta_{i}$ can be estimated directly. Following Chudik, Mohaddes, Pesaran, and Raissi (2016), define $\varphi_{i}(L)=1-\sum_{l=1}^{p_{y i}} \varphi_{i l} L^{l}$, and $\beta_{i}(L)=\sum_{l=0}^{p_{x i}} \beta_{i l} L^{l}$, where $L$ is the lag operator, and rewrite equation (1) to be

$$
\varphi_{i}(L) y_{i, t}=\beta_{i}(L) x_{i, t}+u_{i, t}
$$

Applying $\varphi_{i}^{-1}(L)$ to both sides, we obtain

$$
y_{i, t}=\theta_{i} x_{i, t}+\alpha_{i}(L) \Delta x_{i, t}+\tilde{u}_{i, t}
$$

where

$$
\begin{gathered}
\theta_{i}=\delta_{i}(1), \\
\delta_{i}(L)=\varphi_{i}^{-1}(L) \beta_{i}(L)=\sum_{l=0}^{\infty} \delta_{i l} L^{l}, \\
\alpha_{i}(L)=-\sum_{l=0}^{\infty} \sum_{s=l+1}^{\infty} \delta_{i s} L^{l}, \\
\tilde{u}_{i, t}=\varphi_{i}^{-1}(L) u_{i, t} .
\end{gathered}
$$

Under the usual assumption on the roots of $\varphi_{i}(L)$ falling strictly outside the unit circle, the coefficients of $\alpha_{i}(L)$ are exponentially decaying. Furthermore, in the absence of feedback effects from lagged values of $y_{i, t}$ onto the independent variable $x_{i, t}$, a consistent estimate of $\theta_{i}$ can be obtained by estimating the following truncated distributed lag model for corporate bond $i$ :

$$
y_{i, t}=\theta_{i} x_{i, t}+\sum_{l=0}^{p-1} \delta_{i l} \Delta x_{i, t-l}+\tilde{u}_{i, t}
$$


where the truncated lag order $p$ is chosen appropriately as an increasing function of the time-series length $T$. This approach is often referred to as the DL approach.

Next, based on the estimates of individual pass-throughs $\theta_{i}$, the sample average pass-through can be estimated consistently by the following mean-group estimator:

$$
\hat{\theta}_{M G}=\frac{1}{N} \sum_{i=1}^{N} \hat{\theta}_{i},
$$

where the standard error is calculated nonparametrically.

Both the ARDL and the DL approaches have pros and cons. Most notably, the ARDL approach is consistent irrespective of whether the independent variable $x_{i, t}$ is exogenous or endogenous. But it requires a correct specification of the lag orders $p_{y i}$ and $p_{x i} \cdot{ }^{21}$ Also, for the ARDL approach to account for unobserved common factors $\boldsymbol{f}_{t}$ that can be correlated with $x_{i, t}$, the panel data need to be stationary. The ARDL approach is robust to unit roots only if the unobserved common factors are uncorrelated with regressors and serially uncorrelated themselves. On the other hand, the DL approach requires the independent variable $x_{i, t}$ to be exogenous in that there are no feedback effects from lagged values of $y_{i, t}$ onto $x_{i, t}$. Moreover, the DL approach does not require knowledge of the individual lag orders $p_{y i}$ and $p_{x i}$, because the truncated lag order $p$ can be simply set as an increasing function of the time-series length $T$. It also allows for unit roots in $y_{i, t}, x_{i, t}$, and $\boldsymbol{f}_{t}$, and allows $x_{i, t}$ and $\boldsymbol{f}_{t}$ to be correlated with each other. In the estimation, the effects of $\boldsymbol{f}_{t}$ are controlled for by augmenting the empirical model with the cross-sectional means of the dependent and independent variables, i.e., $\bar{y}_{t}$ and $\bar{x}_{t}$, and their lags. In doing so, the estimator can account for omitted-variable biases and potential cross-sectional dependence caused by such

\footnotetext{
${ }^{21}$ If the specified lag orders are too small, the estimates will be inconsistent; if the specified lag orders are too large, the estimates will be inefficient.
} 
unobserved common factors. It is often referred to as the cross-sectional augmented distributed lag (CS-DL) approach. ${ }^{22}$

In the baseline estimation, we adopt the CS-DL approach, because typically bond yields have unit roots. ${ }^{23}$ The CS-DL approach can do better than the ARDL approach in coping with unobserved common factors in this case. Although the CS-DL approach requires $x_{i, t}$ to be exogenous, we believe that our research design largely satisfies this assumption. Note that $x_{i, t}$ represents the average sovereign yields of a country and $y_{i, t}$ is individual corporate yields. Dittmar and Yuan (2008) find that in emerging markets, in line with intuition, the pricing information flows from the sovereign bond market to the corporate bond market, rather than the reverse, supporting that sovereign bond yields are exogenous to corporate bond yields. ${ }^{24}$ Other papers that have imposed this exogeneity assumption include Bocola (2016) and Bevilaqua, Hale, and Tallman (2020). That said, the recent literature on the European debt crisis also documents a feedback mechanism in which banking-sector credit risks can influence sovereign risks under government bailouts (e.g., Acharya, Drechsler, and Schnabl 2014). However, bailout events are rare in our sample, so this feedback effect should not affect our estimates. Moreover, through Monte Carlo simulations, Chudik, Mohaddes, Pesaran, and Raissi (2016) show that even if the feedback effects

\footnotetext{
${ }^{22}$ Chudik, Mohaddes, Pesaran, and Raissi (2016) document that under certain conditions, this approach does not require knowledge of the number of unobserved common factors. It is also robust to an arbitrary degree of serial correlation in the common factors and the error term, possible structural breaks, and is applicable irrespective of whether the short-run and long-run coefficients are homogeneous or heterogenous across panel individuals.

${ }^{23}$ See Neal, Rolph, Dupoyet, and Jiang (2015), and the references therein, for discussions of unit roots in bond yields. We also test for the existence of unit roots for individual bonds in our sample using the Phillips-Perron test with different lags in Appendix A3. The results show that a majority of individual bond yields contain unit roots, though for a small fraction of bonds, yields are stationary - the CS-DL approach is robust to this model uncertainty.

${ }^{24}$ To illustrate this point, Dittmar and Yuan (2008) utilize variance decompositions in a vector autoregression that consists of emerging-market corporate yield spreads and sovereign yield spreads (over risk-free rates) to assess the contribution of each type of bonds to price discovery.
} 
exist, the bias of the CS-DL estimator is small. In addition, to further mitigate the endogeneity concern, we include a robustness check by estimating the model via the ARDL approach which assumes that corporate bond yields and sovereign bond yields follow a vector autoregressionthus, allowing for causality in both directions - and find the results to be similar. A cost of doing so is that we need to assume that the unobserved common factors $\boldsymbol{f}_{t}$ are uncorrelated with the country-level average sovereign bond yields $x_{i, t}$.

In summary, we consider the following bond-specific regression as our baseline model:

$$
y_{i, t}=c_{y i}+\theta_{i} x_{i, t}+\sum_{l=0}^{p-1} \delta_{i l} \Delta x_{i, t-l}+\sum_{l=0}^{p_{\bar{y}}} \omega_{y, i l} \bar{y}_{t-l}+\sum_{l=0}^{p_{\bar{x}}} \omega_{x, i l} \bar{x}_{t-l}+\boldsymbol{Z}_{i, t}^{\prime} \boldsymbol{\gamma}+e_{i, t},
$$

Where $y_{i, t}$ is the yield of corporate bond $I$ on date $t ; c_{y i}$ is a bond-specific constant term (i.e., bond fixed effects); $x_{i, t-l}$ is the $l$-th (weekly) lag of the average yield of sovereign bonds in the home country of corporate bond $I ; \bar{y}_{t-l}=N^{-1} \sum_{i=1}^{N} y_{i, t-l}$ and $\bar{x}_{t-l}=N^{-1} \sum_{i=1}^{N} x_{i, t-l}$, for all $l$, are crosssectional means to account for the effects of unobserved common factors $\boldsymbol{f}_{t} ; \boldsymbol{Z}_{i, t}$ includes additional observed control variables; and the lag orders $p$ and $p_{\bar{x}}$ are both set to the integer part of $T^{1 / 3}$, and $p_{\bar{y}}$ to 0 , following Chudik, Mohaddes, Pesaran, and Raissi (2017). In our sample, the average number of periods is $T_{\text {avg }}=121$, with the shortest period $T_{\min }=30$, and the longest period $T_{\max }=160$. Thus, we choose the baseline number of lags to be $p=4$, and check for robustness for $p=3$ or $5 .{ }^{25}$ Equation (8) is estimated bond by bond through OLS, and the meangroup estimate $\hat{\theta}_{M G}$ is calculated by equation (7), following Ditzen (2018).

\footnotetext{
${ }^{25}$ Our choice of 4 weekly lags is also in line with the choice of 20 daily lags (trading days) in Dittmar and Yuan (2008).
} 


\section{Full-sample empirical results}

\subsection{Baseline estimates}

The baseline estimation results are in Table 2 , where bond fixed effects $\left(c_{y i}\right)$, distributed lags $\left(\Delta x_{i, t-l}\right)$, and cross-sectional means $\left(\bar{y}_{t-l}\right.$ and $\left.\bar{x}_{t-l}\right)$ are not shown to save space. From columns (1) and (2), we see that (i) the association between corporate bond yields and sovereign bond yields is positive and highly statistically significant; (ii) the long-run pass-through from sovereign yields to corporate yields is around one (i.e., approximately full pass-through); and (iii) there seems to exist a slight downward trend. Notably, even though in these two columns we do not add any control variables explicitly, the CS-DL approach itself has already accounted for possible unobserved common factors $\boldsymbol{f}_{t}$ that may drive both corporate and sovereign bond yields.

In columns (3) and (4), we add multiple control variables: (i) at the bond-level, we control for the average credit rating (i.e., the average across Standard \& Poor's, Moody's, and Fitch ratings), ${ }^{26}$ the number of years to maturity, and bid-ask yield spreads that characterize the extent of illiquidity of the corporate bond; (ii) at the country-level, we include MSCI stock-market returns and volatilities (calculated based on a 30-day rolling window) to capture time-varying country fundamentals and domestic macroeconomic risks, and the growth rates of real and nominal exchange rates, because real appreciation can weaken the country's exporting sector, while nominal appreciation can decrease the country's actual debt burden in domestic currency,

\footnotetext{
${ }^{26}$ If a bond is rated by only two of the three agencies, we use the average of the two ratings. If a bond is rated by only one agency, we use the rating directly. If a bond is unrated by all the three rating agencies, its average rating is assigned to the number 23 (recall the linear assignment for bond ratings assumed above). The rating data is quarterly, and each weekly observation is matched with the most recent ratings.
} 
respectively; ${ }^{27}$ (iii) at the global-level, we consider S\&P 500 stock returns and volatilities (calculated based on the same 30-day rolling window) to control for global economic fundamentals, and U.S. 10-year Treasury yields to represent the credit risk-free rate. ${ }^{28}$

After adding these controls, we find that the sovereign-to-corporate pass-through decreases slightly but remains highly statistically significant. The trend term becomes insignificant; a potential reason is that it is correlated with the number of years to maturity which decreases with time in a deterministic way. The data of MSCI stock indices are available for 31 countries in our sample (whose names are in bold fonts in Appendix A2). However, given that the countries without the MSCI data happen to be those with a small number of bonds, columns (3) and (4) in fact cover 1,987 individual corporate bonds, accounting for more than 97 percent of the entire sample.

Given the results in Table 2, we choose the regression specification in column (3) as our main model. The estimated long-run pass-through is 0.951 , corresponding to the mean-group estimate $\widehat{\theta}_{M G}$ in equation (7), where individual pass-throughs $\hat{\theta}_{i}$ differs from bond to bond. In Figure 1, we show the kernel density of $\widehat{\theta}_{i}$, observing that the individual pass-throughs for some bonds can be extremely large in magnitude, e.g., below -50 or almost reaching 100 . A potential reason is that the CS-DL method may not perform well for these bonds, perhaps due to technical reasons, such as the roots of $\varphi_{i}(L)$ falling close to the unit circle (see equations 4 and 5).

Based on the estimates in column (3) of Table 2, we trim the sample of corporate bonds at the top and bottom 5 percent of $\hat{\theta}_{i}$ to remove the impact of outlier bonds, where 200 bonds are

\footnotetext{
${ }^{27}$ For real exchange rates, we use the country's real effective exchange rates, where a positive growth rate represents domestic real appreciation. For nominal exchange rates, we use the bilateral exchange rates between the country's domestic currency and U.S. dollar, defined as the domestic currency price of one U.S. dollar, and thus a positive growth rate indicates domestic depreciation. The data of real exchange rates are monthly and those of nominal exchange rates are quarterly. Each weekly observation is matched with the most recent exchange rates. In addition, the results here are also robust to including either the real or the nominal exchange rate growth separately.

${ }^{28}$ Our results are robust to using U.S. 3-, 5-, or 7-year Treasury yields as the risk-free rate instead.
} 
dropped. The remaining 1,787 bonds are referred to as the trimmed-full sample henceforth. Repeating the estimation in Table 2 leads to similar results shown in Table 3. We can see that the average pass-through decreases slightly in each column, but the standard error becomes much smaller, suggesting a more precise estimate. For the main specification in column (3), the passthrough is estimated to be 0.824 and statistically significant at the 1 percent level. In addition, corporate bond yields increase with the bond's maturity, its home country's stock-market volatility, and real exchange rate appreciation, all in line with our expectations. The distribution of individual pass-throughs is reported in Figure 2. Henceforth, we focus on this trimmed-full sample to present our results to mitigate the concern for outliers, but all the results are robust to the original full sample. ${ }^{29}$

\subsection{Robustness}

Our baseline results in column (3) of Table 3 are robust to a list of robustness checks. In Table 4, we report the mean-group estimates of the long-run pass-throughs from sovereign yields to corporate yields for the following specifications..$^{30}$ First, instead of matching each corporate bond with a portfolio of sovereign bonds, we find the sovereign bond (still of the same country) that is

\footnotetext{
${ }^{29}$ As in Figure 2, the individual pass-throughs are negative for some corporate bonds. Particularly, for a small fraction of them (274 bonds), the negative pass-throughs are significantly nonzero. For these corporate bonds, their credit risks seem to be negatively related to default risks of their home countries' sovereigns. We find that this is unlikely due to the business models of these corporate issuers being counter-cyclical, because when we compare the distribution of issuers across different industries of these 274 bonds to that of the remaining bonds, we do not find any significant differences. On the other hand, we notice that more than 80 percent of these 274 bonds are issued by companies in China. There are many reasons why China may be different from other emerging economies in our sample. For instance, the sovereign default risks on their external debt are low given the country's large foreign reserves. Moreover, the purpose of the Chinese government issuing U.S. dollar debt is largely not due to actual funding needs (Flannery, Hong, and Wang 2020). In addition, some Chinese firms may gain or lose government supports due to political reasons that are difficult to detect in data. Further exploring what causes the negative sovereign-to-corporate pass-throughs is beyond the scope of this paper. We instead conduct robustness checks by dropping these 274 bonds from our sample, finding that all our results remain robust (available upon request).

${ }^{30}$ In each case, all the control variables in column (3) of Table 3, bond fixed effects, distributed lags, and crosssectional means are included but their coefficients are not reported to save space.
} 
closest to the corporate bond in terms of maturities, credit ratings, and bid-ask yield spreads. Specifically, in column (1) of Table 4, we pair each corporate bond with the sovereign bond that minimizes the mean-absolute distance (MAD) between the maturities of the two bonds. In column (2), we minimize the mean-squared distance (MSD) between bond maturities. In columns (3) and (4), we instead consider maturities, credit ratings, and bid-ask yield spreads simultaneously. ${ }^{31}$ The estimated pass-throughs for these four cases are similar, and all highly significant, however, the magnitudes are slightly smaller than our baseline estimates.

In column (5), we return to the baseline bond matches, but further control for additional macroeconomic variables: real GDP growth, CPI inflation, real GDP per capita, and the ratio of current account balance to GDP, following Bevilaqua, Hale, and Tallman (2020). All of these variables are recorded at annual frequency, and we pair each weekly observation with the data of the previous year. In column (6), we instead control for issuers' key financial variables: profit margin, leverage, asset tangibility, and interest coverage. These data are recorded at quarterly frequency, and we match each weekly observation with the most recent quarterly data. However, such financial data of issuers are available for only a small fraction of bonds in our sample. In column (7), we drop bonds issued by companies from China, since these bonds constitute the largest part of our sample, and we need to ensure that they do not drive the results. In column (8), we keep only bonds with most common features: fixed-coupon, senior-unsecured, and without any embedded options (Durbin and Ng 2005). In columns (9) and (10), we consider the distributed lag

\footnotetext{
${ }^{31}$ For corporate bond $i$ and sovereign bond $j$, the MAD between their maturities is calculated as $T^{-1} \sum_{t=1}^{T}\left|m_{i, t}-m_{j, t}\right|$, where $m_{i, t}$ and $m_{j, t}$ represent the number of years to maturity of bond $i$ and $j$, respectively, on date $t$. The MSD between their maturities is calculated as $T^{-1} \sum_{t=1}^{T}\left|m_{i, t}-m_{j, t}\right|^{2}$. The MAD accounting for maturities, credit ratings, and bid-ask yield spreads simultaneously is calculated as $T^{-1} \sum_{t=1}^{T}(1 / 3)\left(\left|m_{i, t}-m_{j, t}\right|+\left|r_{i, t}-r_{j, t}\right|+\left|s_{i, t}-s_{j, t}\right|\right)$, where $r$ represents the average rating by Standard \& Poor's, Moody's, and Fitch, and $s$ represents the bid-ask yield spread. The corresponding MSD is calculated as $T^{-1} \sum_{t=1}^{T}(1 / 3)\left(\left|m_{i, t}-m_{j, t}\right|^{2}+\left|r_{i, t}-r_{j, t}\right|^{2}+\left|s_{i, t}-s_{j, t}\right|^{2}\right)$.
} 
order equal to 3 and 5, respectively. In column (11), we estimate the model with the panel ARDL approach developed in Pesaran and Smith (1995) and Pesaran, Shin, and Smith (1999), which allows for feedback effects from corporate bond yields to sovereign bond yields, reporting the mean-group estimates. Finally, in column (12), we estimate the model with the time-series ARDL approach developed in Pesaran, Shin, and Smith (2001), where the time series is synthesized using the panel data in a pooled way following Bevilaqua, Hale, and Tallman (2020). ${ }^{32}$ In each of these cases, we find a highly significant long-run pass-through from sovereign yields to corporate yields, and for most of them, the estimates are similar to the baseline estimates. ${ }^{33}$

Furthermore, our results are robust to replacing corporate and sovereign bond yields with credit spreads. Specifically, we obtain data of Z spreads for corporate bonds from IHS Markit and for sovereign bonds from Bloomberg. ${ }^{34} \mathrm{We}$ find that in our baseline specification, the long-run passthrough from sovereign spreads to corporate spreads is estimated to be 0.831 , which is close to the pass-through from sovereign yields to corporate yields, i.e., 0.824 . This evidence suggests that the

\footnotetext{
${ }^{32}$ We do so by appending each bond's weekly time series to the previous bond's time series. The new synthetic "time" variable is simply a counter of observations, corresponding to time periods for bond 1 , then continuing the counter for country 2, etc.; see footnote 13 of Bevilaqua, Hale, and Tallman (2020) for more details. This approach allows us to run a time-series estimator towards the panel data, while simultaneously accounting for cross-sectional as well as time-series variation in the data. A potential issue of doing so is that the estimation results would depend on the order of bonds in the panel data. We mitigate this concern by randomly shuffling the order of bonds and repeating the estimation 2000 times. The long-run pass-through and its standard error reported in column (12) of Table 4 are the mean of the 2000 estimates. In fact, the estimates obtained in each iteration are quite similar, ranging from 0.87 to 1.02 for the pass-through, and between 0.039 and 0.042 for the standard error.

${ }^{33}$ In addition, our baseline results are robust to further controlling for (1) time fixed effects (at monthly frequency, which is to avoid multicollinearity with the weekly cross-sectional mean variables, $\bar{y}_{t-l}$ and $\left.\bar{x}_{t-l}\right)$; (2) monthly excess bond premium in Gilchrist and Zakrajsek (2012) that captures investor risk aversion; (3) the ratio of portfolio investment to GDP of each country at quarterly frequency that represents cross-border capital flows (we consider net, asset, and liability flows separately); (4) weekly Moody's U.S. Aaa corporate index yields; (5) weekly Moody's U.S. Baa corporate index yields; (6) oil price weekly growth; and (7) all the variables in (2)-(6) simultaneously. Results are reported in Appendix A4.

${ }^{34}$ The benchmark securities that represent risk-free rates are chosen by the corresponding data provider.
} 
corporate-sovereign association we find is unlikely driven by risk-free rates. Results are reported in Appendix A5.

\section{Transmission channels}

Thus far, we have shown that corporate bond yields are strongly related to the sovereign bond yields of their home country, and the long-run sovereign-to-corporate pass-through is highly significant even after controlling for common economic factors (both observed and unobserved). In this section, we aim to investigate what causes this relation through subsample analysis. Specifically, we examine the transfer-risk channel and the liquidity-premium channel, inspired by the theoretical literature.

\subsection{Transfer-risk channel}

We first consider the possibility of sovereigns transferring credit risks to their domestic firms. Following this logic, it is reasonable to predict that governments with greater sovereign risks are more likely to offload them onto the private sector. Thus, if the transfer-risk channel is a crucial reason leading to the corporate-sovereign nexus in bond yields, we should observe that in countries with greater sovereign risks, the pass-through from sovereign yields to corporate yields is larger.

We examine this prediction by dividing our sample according to sovereign credit ratings and the ratio of public external debt to foreign reserves. ${ }^{35}$ Countries with investment-grade ratings and relatively low debt-to-reserve ratios are regarded as low-risk countries, and vice versa. Given that our estimation utilizes time-series variation of individual bonds, we need to avoid breaking the time-series data of any given bond when dividing the sample. In particular, we categorize a country to be investment-grade (IG) if the mean of its sovereign bonds' average ratings is better than or

\footnotetext{
${ }^{35}$ We use public external debt rather than total public debt because our focus is on external sovereign risks and the bonds that we consider are all denominated in U.S. dollars.
} 
equal to BBB-. Herein, the "average rating" is defined towards any given individual sovereign bond on any given date, being the average across the ratings issued by Standard \& Poor's, Moody's, and Fitch (if available). Then, the mean of the "average rating" is taken across all individual sovereign bonds issued by this country and across all dates in our sample. Regarding the debt-to-reserve ratio, because this variable is recorded at annual frequency, we first construct a country-year panel of the 31 countries in our sample between 2015 and 2018 (which corresponds to the weekly bond data between 2016 and 2019) and obtain the pooled median of this panel. Then, we calculate the time-series mean of the debt-to-reserve ratio for each country across 2015-2018 and classify a country to be a low-risk country if this mean is below the pooled median obtained from the previous step. In doing so, we divide the 31 countries into two groups, with the low-risk group consisting of 15 countries and the high-risk group including 16 countries. ${ }^{36}$

The estimates for these subsamples are reported in Table 5, columns (1)-(4). We observe that the pass-through from sovereign yields to corporate yields in high-risk countries almost doubles that in low-risk countries, irrespective of whether the low- and high-risk countries are defined by sovereign ratings or by debt-to-reserve ratios. These results support the transfer-risk mechanism.

Furthermore, because government-related firms (irrespective of their business industries) and financial companies holding government debt on their balance sheets can be more directly exposed to transfer risks, we expect their bond yields to be more sensitive to sovereign yields. To test this prediction, we utilize the Bloomberg variable industrygroup to determine whether an issuer is a financial company. The government-related issuers instead refer to those that are classified as

\footnotetext{
${ }^{36}$ We include 31 countries in this exercise because we follow the empirical model in column (3) of Table 3 and only these 31 countries have the MSCI stock data available. That said, our results remain the same if we instead use the data of all 46 countries to define the low-risk and high-risk groups. Moreover, because countries in the low-risk group have more corporate bonds, this sample-split creates an uneven distribution of the number of bonds.
} 
"government-related" by IHS Markit, and those classified as "government-guaranteed", "government-owned", or "government-sponsored" by Bloomberg.

In columns (5)-(8) of Table 5 , we show that this prediction is only partially supported by the data. The pass-through for financial firms' bonds is much larger than that for non-financial firms' bonds, consistent with our expectation. However, the pass-through for government-related bonds is only half of that for bonds issued by firms without government relations, contradicting our conjecture.

To further explore this unexpected result, in columns (9)-(12), we double-sort the sample based on whether a bond's issuer operates in the financial sector and whether it is related to governments. This is because we suspect that government relations might play a different role within and outside the financial sector. Our findings indicate that, in non-financial sectors, the pass-through is higher for government-related bonds than for non-government-related bonds, in line with our prediction. But within the financial sector, the pass-through is higher for non-government-related bonds. The pass-through for bonds issued by government-related financial companies is instead small and insignificant from zero—-we find that this insignificant result partially lies in Chinese banks in our sample. ${ }^{37}$ To see this, in columns (13)-(16), we repeat the exercises of columns (9)-(12) while dropping bonds from China. The pass-throughs in all columns increase compared to the case when Chinese bonds are included in the sample. Outside the financial sector, same as previously observed, the pass-through for government-related bonds is larger than that for non-government-

\footnotetext{
${ }^{37}$ Conceptually, bonds from China can behave different from other bonds in our sample, especially those issued by government-related banks, because Chinese state-owned banks are gigantic compared to other financial companies in emerging economies. Moreover, the Chinese government has always provided strong guarantees on these banks. In addition, China's external sovereign risks may be low given the country's large foreign reserves. All these reasons can lead to the bond yields of Chinese state-owned banks being insensitive to the country's sovereign yields.
} 
related bonds. Within the financial sector, the pass-through for government-related bonds becomes significant, but is still lower than that for non-government-related bonds..$^{38}$

The last empirical evidence indicates that, in sovereign distress, banks without government relations are more likely to be vulnerable than government-related banks. This evidence contradicts the notion of "moral suasion" in the literature (Becker and Ivashina 2017; Ongena, Popov, and Van Horen 2019; Chari, Dovis, and Kehoe 2020), which states that sovereigns might "suggest" their related banks to increase sovereign bond holdings in case of difficulties in refinancing government debt. In the moral suasion channel, government-related banks should be more, rather than less, sensitive to sovereign risks. But the evidence we find is consistent with Acharya, Eisert, Eufinger, and Hirsch (2018) who document that, in Greece, Ireland, Italy, Portugal, and Spain, government-controlled banks increased their holdings of sovereign bonds less than comparable banks that were not government-controlled during the European sovereign debt crisis.

\subsection{Liquidity-premium channel}

We then consider the corporate-sovereign linkage in bond yields through the bonds' liquidity premiums. Yuan (2005) and Dittmar and Yuan (2008) have documented that for an emerging economy, U.S. dollar denominated sovereign bonds can act as benchmark securities and hedging instruments, thus improving the liquidity of the country's U.S. dollar denominated corporate bonds. The more liquid sovereign bonds are, the more effective this role is. This mechanism leads

\footnotetext{
${ }^{38}$ Given that the subsample in column (13) contains only 57 bonds, there is a possibility — which we cannot rule out-that this result is not universal but instead driven by a small number of bonds with some special features. That said, we have checked the credit ratings, maturities, and bid-ask spreads of these bonds, as well as their sovereigns, finding no evidence that the result is due to these features.
} 
to a positive association between corporate and sovereign bond yields, because both yields are driven by the liquidity premiums of sovereign bonds.

Following this logic, we expect that the sensitivity of corporate yields to sovereign yields should be larger in countries where sovereign bonds are relatively more liquid. This is because in those countries sovereign bonds are more likely to be adopted by traders as benchmarks and used for hedging, and therefore play a bigger role in determining the pricing of corporate bonds.

To test this prediction, we use bid-ask yield spreads to measure the liquidity of sovereign bonds. We divide countries into a low-bid-ask (LBA) group in which sovereign bonds are relatively more liquid, and a high-bid-ask (HBA) group in which sovereign bonds are relatively less liquid. Specifically, for each country and on each date, we first calculate the average bid-ask yield spread of the equal-weighted sovereign bond portfolio (which includes all sovereign bonds of this country with non-missing data on this date). This produces a weekly panel of the 31 countries on which we focus, and we obtain the sample median of this panel. We then calculate the time-series mean of the average bid-ask yield spreads for each country and compare this timeseries mean with the panel median in the previous step. A country is classified as an LBA country if its time-series mean is lower than the panel median, and vice versa. We obtain 15 LBA countries and 16 HBA countries.

Moreover, because bonds with better credit ratings are naturally more liquid, we need to control for the influences of bond ratings. Thus, we double sort the 31 countries based on LBA/HBA and whether a country is classified as investment-grade as in section 5.1 to obtain four subsamples. The estimates are reported in Table 6. By comparing columns (1) and (2), we see that within investment-grade countries, the sensitivity of corporate bond yields to sovereign bond yields is significant in LBA countries, but insignificant in HBA countries. In columns (3) and (4), 
we see that within non-investment-grade countries, the association in corporate and sovereign yields is larger for LBA countries than for HBA countries. These results are in line with the liquidity-premium channel. In addition, if we compare column (1) to column (3), and also (2) to (4), we observe that within LBA (or HBA) countries, the pass-through from sovereign to corporate yields is larger in non-investment-grade countries than in investment-grade countries. These results are consistent with those in section 5.1, supporting the transfer-risk channel. Thus, both channels exist, and they simultaneously drive the observed corporate-sovereign association in bond yields.

\section{Further exploration}

\subsection{Credit ratings and maturities}

Next, we explore how the pass-through from sovereign to corporate yields changes with corporate bonds' credit ratings and maturities. This is to understand which types of corporate bonds are most vulnerable to sovereign risks. We assign each corporate bond into either an investmentgrade group or a non-investment-grade group based on whether the time-series mean of the bond's ratings is better than $\mathrm{BBB}$ - or not. ${ }^{39}$ Regarding maturities, we categorize a bond as a short-term bond if the time-series mean of its years to maturity is between 1 year and 5 years, a mid-term bond if the mean of maturity is between 5 years and 10 years, and a long-term bond if the mean of maturity is over 10 years.

The subsample results are presented in Table 7. From columns (1) and (2), we find that the pass-through is larger for non-investment-grade corporate bonds than for investment-grade

\footnotetext{
${ }^{39}$ Like before, we calculate the time-series mean of each corporate bond's average ratings across the ratings given by Standard \& Poor's, Moody's, and Fitch, when available. Moreover, non-investment-grade bonds are mostly junk bonds, but contain a small fraction (around 5 percent) of bonds unrated by any of the three rating agencies.
} 
corporate bonds. This result is in line with our intuition: in the standard financial-friction literature, the default premium is convex in the default risk; thus, corporate bonds that are riskier themselves are more vulnerable to transfer risks.

On the other hand, from columns (3)-(5), we observe that the sensitivity of corporate bond yields to sovereign bond yields is the highest for short-term corporate bonds, lower for mid-term corporate bonds, and much lower for long-term corporate bonds. We speculate that a possible reason for this is that, for mid- and long-term bonds, a large fraction of the repayment (i.e., their face values) is not due in 5 or 10 years. ${ }^{40}$ Although, conceptually, sovereigns could still transfer credit risks to these bonds through increased taxation, reduced government guarantees, and impaired financial intermediation, it is unlikely that the effects would remain as strong after more than 5 or 10 years. Thus, investors holding these corporate bonds are less concerned about the current sovereign risks, resulting in corporate bond yields behaving less sensitive to sovereign bond yields.

\subsection{Nonlinearity}

Bevilaqua, Hale, and Tallman (2020) document an increasing, but concave, relation between the primary yields of corporate bonds at issuance and the 10 -year sovereign yields of the home country on dates when the corporate bonds are issued. They explain this nonlinear relation through an information model, in which sovereign yields contain noisy public information about the creditworthiness of corporate bond issuers. When sovereign yields are high, the information value declines, and therefore, corporate yields are less sensitive to sovereign yields, referred to as the "information-provision channel” below.

\footnotetext{
${ }^{40}$ Given that most bonds in our sample are coupon bonds, to account for the potential influences of differences in coupon rates, we also use bond durations to replace maturities and obtain similar results. The results are also robust to whether we use Macauley durations, modified durations, or effective durations.
} 
In this subsection, we aim to investigate whether this nonlinear effect also exists in the relation between secondary corporate and sovereign yields. In Table 8, columns (1) and (3) are the same as those in Table 3, and we include a squared term of sovereign yields in columns (2) and (4) to capture the potential nonlinearity, like in Bevilaqua, Hale, and Tallman (2020). We see that the squared term is significant only when control variables are omitted in column (2). In contrast, in column (4) when control variables are added, the coefficient of the squared term becomes much smaller and insignificant from zero. Moreover, even if we consider the estimates in column (2), the nonlinear relation between corporate bond yields and sovereign bond yields is increasing and convex, rather than concave; see Figure 3 for the fitted curve. That is, the pass-through from sovereign yields to corporate yields is larger when sovereign yields are higher. This finding is in line with our previous results that the pass-through is larger in countries with non-investmentgrade ratings, or those with relatively higher external debt, all supporting the transfer-risk channel.

Even though our results are different from those in Bevilaqua, Hale, and Tallman (2020), we believe the two papers are in fact complementary. Their paper focuses on primary corporate yields, and their estimates capture largely the cross-sectional variation across different bond issuances. In contrast, we investigate the co-dynamics of secondary corporate bond yields and sovereign bond yields in the time series. Interpreting their results together with ours, we may infer that the information-provision channel dominates in the cross section and in primary markets, and the transfer-risk channel is more prominent in the time series and in secondary markets.

\section{Concluding remarks}

We examine the long-run impact of sovereign bond yields on corporate bond yields of the same country, using a large dataset that covers more than 2,400 U.S. dollar-denominated bonds in 46 emerging markets. We show that, on average, the long-run pass-through from sovereign yields to 
corporate yields is around one and highly significant. It also displays great cross-country and crossbond heterogeneity that is consistent with the theoretical notion that governments can transfer credit risks to domestic firms, and that sovereign bonds can affect corporate bond pricing through influencing liquidity. This transfer-risk channel and the liquidity-premium channel have been predicted, or used as model input, in many theoretical studies, but yet, received little attention in the empirical literature. Our work provides empirical support for such theoretical models. ${ }^{41}$

This paper also fits into the long-lasting discussion of deficits and growth. In particular, our results illustrate that fiscal distress that causes high sovereign yields has a persistent spillover effect on private sector borrowing costs, and therefore, may impede growth for an extended period of time. This perspective relates to Reinhart and Rogoff (2004) who document that sovereign risks are highly persistent, and to Arteta and Hale (2008) who find that emerging-market sovereign debt crises are systematically accompanied by a decline in foreign credit to domestic firms, and that this effect can persist for a considerably long time after debt restructuring agreements are reached.

\footnotetext{
${ }^{41}$ That said, we do not claim that the transfer-risk and liquidity-premium channels are the only reasons for the observed linkage between corporate and sovereign bond yields. Despite that our subsample analysis shows empirical evidence consistent with the two channels, we cannot rule out other channels leading to the same subsample results - especially when the alternative channels are correlated with sovereign risks and the liquidity of sovereign bonds. A potential way to address this concern is to directly study the default risks and liquidity risks of corporate and sovereign bonds. However, doing so often requires data of CDS contracts, issuers' financial positions, and bond transaction prices/volumes, which are hard to obtain for emerging-market bonds. We therefore leave this for future research.
} 


\section{References}

Acharya, V., T. Eisert, C. Eufinger, and C. Hirsch. 2018. Real effects of the sovereign debt crisis in Europe: Evidence from syndicated loans. The Review of Financial Studies 31:2855-96.

Acharya, V., I. Drechsler, and P. Schnabl. 2014. A pyrrhic victory? Bank bailouts and sovereign credit risk. The Journal of Finance 69:22-1082.

Adelino, M., and M. A. Ferreira. 2016. Bank ratings and lending supply: Evidence from sovereign downgrades. The Review of Financial Studies 29(7): 1709-1746.

Ağca, S., and O. Celasun. 2012. Sovereign debt and corporate borrowing costs in emerging markets. Journal of International Economics 88:198-208.

Albertazzi, U., T. Ropele, G. Sene, and F. M. Signoretti. 2014. The impact of the sovereign debt crisis on the activity of Italian banks. Journal of Banking \& Finance 46:387-402.

Almeida, H., I. Cunha, M. A. Ferreira, and F. Restrepo. 2017. The real effects of credit ratings: The sovereign ceiling channel. The Journal of Finance 72(1): 249-290.

Arteta, C., G. Hale. 2008. Sovereign debt crises and credit to the private sector. Journal of International Economics 74:53-69.

Augustin, P., H. Boustanifar, J. Breckenfelder, and J. Schnitzler. 2018. Sovereign to corporate risk spillovers. Journal of Money, Credit and Banking 50:857-91.

Bai, J., S. Wei. 2012. When is there a strong transfer risk from the sovereigns to the corporates? Property rights gaps and CDS spreads. Working Paper, National Bureau of Economic Research.

Bedendo, M., P. Colla. 2015. Sovereign and corporate credit risk: Evidence from the Eurozone. Journal of Corporate Finance 33:34-52.

Bekaert, G., C. R. Harvey, and C. Lundblad. 2007. Liquidity and expected returns: Lessons from emerging markets. The Review of Financial Studies 20(6): 1783-1831.

Bevilaqua, J., G. B. Hale, and E. Tallman. 2020. Corporate yields and sovereign yields. Journal of International Economics 124.

Bocola, L. 2016. The pass-through of sovereign risk. Journal of Political Economy 124:879-926.

Borensztein, E., K. Cowan, and P. Valenzuela. 2013. Sovereign ceilings "lite"? The impact of sovereign ratings on corporate ratings. Journal of Banking \& Finance 37(11): 4014-4024.

Cavallo, E. A., and P. Valenzuela. 2009. The determinants of corporate risk in emerging markets: An option-adjusted spread analysis. International Journal of Finance \& Economics 15:59-74.

Chudik, A., K. Mohaddes, M. H. Pesaran, and M. Raissi. 2013. Debt, inflation and growth: Robust estimation of long-run effects in dynamic panel data models. CAFE Research Paper No. 13.23. 
Chudik, A., K. Mohaddes, M. H. Pesaran, and M. Raissi. 2016. Long-run effects in large heterogeneous panel data models with cross-sectionally correlated errors. Essays in Honor of Man Ullah (Advances in Econometrics) 36:85-135.

Chudik, A., K. Mohaddes, M. H. Pesaran, and M. Raissi. 2017. Is there a debt-threshold effect on output growth? Review of Economics and Statistics 99(1): 135-150.

Cooper, R, and K. Nikolov. 2018. Government debt and banking fragility: The spreading of strategic uncertainty. International Economic Review 59:1905-25.

Corsetti, G., K. Kuester, A. Meier, and G. J. Müller. 2014. Sovereign risk and belief-driven fluctuations in the euro area. Journal of Monetary Economics 61:53-73.

Dailami, M. 2010. Sovereign debt distress and corporate spillover impacts. Working Paper, World Bank Policy Research Working Papers.

Dittmar, R. F., and K. Yuan. 2008. Do sovereign bonds benefit corporate bonds in emerging markets? Review of Financial Studies 21:1983-2014.

Ditzen, J. 2018. xtdcce2: Estimating dynamic common correlated effects in Stata. The Stata Journal. 18:3, 585 - 617.

Durbin, E., D. Ng. 2005. The sovereign ceiling and emerging market corporate bond spreads. Journal of International Money and Finance 25:631-49.

Eichengreen, B., A. Mody. 2000. "What explains changing spreads on emerging market debt?" in Capital Flows and the Emerging Economies: Theory, Evidence, and Controversies, ed. Edwards, S. (University of Chicago Press), 107-134.

Farhi, E., and J. Tirole. 2018. Deadly embrace: Sovereign and financial balance sheets doom loops. The Review of Economic Studies 85:1781-823.

Flannery, M. J., C.Y. Hong, and B. Wang. 2020. The effect of government reference bonds on corporate borrowing costs: Evidence from a natural experiment. Working Paper, Hong Kong Institute for Monetary and Financial Research.

Gennaioli, N., A. Martin, and S. Rossi. 2013. Sovereign default, domestic banks, and financial institutions. The Journal of Finance 69:819-66.

Gilchrist, S., and E. Zakrajšek. 2012. Credit spreads and business cycle fluctuations. American Economic Review 102(4): 1692-1720.

Harjes, T. 2011. Financial integration and corporate funding costs in Europe after the financial and sovereign debt crisis. Working Paper, IMF Working Paper.

Li, J., and G. Zinna. 2018. How much of bank credit risk is sovereign risk? Evidence from Europe. Journal of Money, Credit and Banking 50:1225-69. 
Mendoza, E. G., and V. Z. Yue. 2011. A general equilibrium model of sovereign default and business cycles. Working Paper, IMF Working Paper.

Mendoza, E. G., and V. Z. Yue. 2012. A general equilibrium model of sovereign default and business cycles. The Quarterly Journal of Economics 127:889-946.

Neal, R., D. Rolph, B. Dupoyet, and X. Jiang. 2015. Interest rates and credit spread dynamics. The Journal of Derivatives 23:25-39.

Neri, S. 2013. The impact of the sovereign debt crisis on bank lending rates in the euro area. Working Paper, Bank of Italy Questioni di Economia e Finanza.

Neumeyer, P. A., and F. Perri. 2005. Business cycles in emerging economies: The role of interest rates. Journal of Monetary Economics 52:345-80.

Pesaran, M.H., and R. Smith. 1995. Estimating long-run relationships from dynamic heterogeneous panels. Journal of Econometrics 68(1): 79-113.

Pesaran, M.H., Y. Shin, and R. Smith. 1999. Pooled mean group estimation of dynamic heterogeneous panels. Journal of the American Statistical Association, 94(446): 621-634.

Pesaran, M.H., Y. Shin, and R. Smith. 2001. Bounds testing approaches to the analysis of level relationships. Journal of Applied Econometrics 16(3): 289-326.

Peter, M., and M. Grandes. 2005. How important is sovereign risk in determining corporate default premia? The case of South Africa. Working Paper, International Monetary Fund.

Reinhart, C. M., and K. S. Rogoff. 2004. Serial default and the "paradox" of rich-to-poor capital flows. American Economic Review 94:53-58.

Schestag, R., P. Schuster, and M. Uhrig-Homburg. 2016. Measuring liquidity in bond markets. The Review of Financial Studies 29(5): 1170-1219.

Uribe, M., and V. Z. Yue. 2006. Country spreads and emerging countries: Who drives whom? Journal of International Economics 69:6-36.

Zinna, G. 2014. Identifying risks in emerging market sovereign and corporate bond spreads. Emerging Markets Review 20:1-22.

Zoli, E. 2013. Italian Sovereign Spreads: Their determinants and pass-through to bank funding costs and lending conditions. Working Paper, IMF Working Paper. 
Table 1. Summary statistics

\begin{tabular}{|c|c|c|c|c|c|c|}
\hline & \#Obs. & Mean & St.dev. & $\mathrm{p} 25$ & $\mathrm{p} 50$ & $\mathrm{p} 75$ \\
\hline Mid yields (\%) & 263,103 & 5.57 & 3.69 & 3.77 & 4.78 & 6.31 \\
\hline Average ratings $(\mathrm{AAA}=1$, defaulted $=22)$ & 263,103 & 11.17 & 4.39 & 8 & 10.33 & 13.67 \\
\hline Number of years to maturity & 263,103 & 7.91 & 8.71 & 3.02 & 4.99 & 8.74 \\
\hline Bid-ask yield spread (\%) & 263,103 & 0.19 & 0.3 & 0.06 & 0.11 & 0.21 \\
\hline Country stock returns (30-day \%) & 198,744 & 0.74 & 5.99 & -3.13 & 0.7 & 4.5 \\
\hline Country stock volatilities (30-day \%) & 198,744 & 5.74 & 2.31 & 4.21 & 5.25 & 6.64 \\
\hline Nominal USD exchange rate growth (quarterly \%) & 205,140 & 1.12 & 5.22 & -1.44 & 0.41 & 2.52 \\
\hline Real effective exchange rate growth (monthly \%) & 205,140 & 0.04 & 2.23 & -0.97 & 0.04 & 0.87 \\
\hline Real GDP growth (annual \%) & 205,140 & 3.79 & 3.14 & 1.73 & 3.36 & 6.9 \\
\hline CPI growth (annual \%) & 201,676 & 4.43 & 5.45 & 1.80 & 2.52 & 4.88 \\
\hline Current account balance / GDP (annual \%) & 205,140 & -0.44 & 2.94 & -2.34 & -0.73 & 1.8 \\
\hline Real GDP per capita (2010 USD) & 205,140 & 9971 & 7966 & 6884 & 7755 & 10990 \\
\hline Total external debt / foreign reserves (annual \%) & 205,074 & 236.2 & 344.5 & 55.65 & 179 & 277.8 \\
\hline S\&P 500 returns (30-day \%) & 205,140 & 0.89 & 3.28 & -0.35 & 1.25 & 2.73 \\
\hline S\&P 500 volatilities (30-day \%) & 205,140 & 3.34 & 1.82 & 2.03 & 2.62 & 4.14 \\
\hline US 10-year Treasury yields (\%) & 205,140 & 2.5 & 0.45 & 2.26 & 2.55 & 2.87 \\
\hline
\end{tabular}

Note: On a given date, the average rating of a bond is the average of numeric ratings by Standard \& Poor's, Moody's, and Fitch, when available; if a bond is unrated by all the three rating agencies, its average rating is assigned to the number 23 . Country stock returns and volatilities are calculated based on a 30 -day rolling window using MSCI stock indices for each country. S\&P 500 returns and volatilities utilize the same 30-day rolling-window method. Other variables are defined accordingly in the table. P25, p50, and p75 refer to the 25-, 50-, and 75-percentile value, respectively. For mid yields, average ratings, number of years to maturity, and bid-ask yield spreads, the summary statistics are of observations of all bonds including both corporate bonds and sovereign bonds; for other variables, the summary statistics are toward observations of corporate bonds. 
Table 2. Baseline estimates (full sample)

\begin{tabular}{|c|c|c|c|c|}
\hline & $\begin{array}{c}\text { (1) } \\
\text { Corp. yields }\end{array}$ & $\begin{array}{c}\text { (2) } \\
\text { Corp. yields }\end{array}$ & $\begin{array}{c}\text { (3) } \\
\text { Corp. yields }\end{array}$ & $\begin{array}{c}\text { (4) } \\
\text { Corp. yields }\end{array}$ \\
\hline Sovereign yields & $\begin{array}{c}1.165 * * * \\
(0.144)\end{array}$ & $\begin{array}{c}0.995 * * * \\
(0.108)\end{array}$ & $\begin{array}{c}0.951 * * * \\
(0.111)\end{array}$ & $\begin{array}{c}0.951^{* * *} \\
(0.111)\end{array}$ \\
\hline Average ratings & & & $\begin{array}{c}-0.000318 \\
(0.0368)\end{array}$ & $\begin{array}{c}-0.000318 \\
(0.0368)\end{array}$ \\
\hline Number of years to maturity & & & $\begin{array}{c}0.258^{* *} \\
(0.112)\end{array}$ & $\begin{array}{c}0.140 \\
(0.142)\end{array}$ \\
\hline Bid-ask yield spread & & & $\begin{array}{c}2.652 \\
(2.454)\end{array}$ & $\begin{array}{c}2.652 \\
(2.454)\end{array}$ \\
\hline Country stock returns & & & $\begin{array}{c}0.000103 \\
(0.000744)\end{array}$ & $\begin{array}{c}0.000103 \\
(0.000744)\end{array}$ \\
\hline Country stock volatilities & & & $\begin{array}{c}0.00464 \\
(0.00340)\end{array}$ & $\begin{array}{c}0.00464 \\
(0.00340)\end{array}$ \\
\hline Real effective exchange rate growth & & & $\begin{array}{c}0.0189 * * * \\
(0.00446)\end{array}$ & $\begin{array}{c}0.0189 * * * \\
(0.00446)\end{array}$ \\
\hline Nominal USD exchange rate growth & & & $\begin{array}{c}0.00324 \\
(0.00577)\end{array}$ & $\begin{array}{c}0.00324 \\
(0.00577)\end{array}$ \\
\hline S\&P500 stock returns & & & $\begin{array}{r}-0.000547 \\
(0.00117)\end{array}$ & $\begin{array}{r}-0.000547 \\
(0.00117)\end{array}$ \\
\hline S\&P500 stock volatilities & & & $\begin{array}{c}0.00714 * * \\
(0.00306)\end{array}$ & $\begin{array}{c}0.00714^{* *} \\
(0.00306)\end{array}$ \\
\hline US 10-year Treasury yields & & & $\begin{array}{c}-0.147^{* *} \\
(0.0665)\end{array}$ & $\begin{array}{l}-0.147^{* *} \\
(0.0665)\end{array}$ \\
\hline Time trend & & $\begin{array}{c}-0.00237^{*} \\
(0.00138)\end{array}$ & & $\begin{array}{c}-0.00226 \\
(0.00260)\end{array}$ \\
\hline Bond fixed effects & $\mathrm{Y}$ & $\mathrm{Y}$ & $\mathrm{Y}$ & $\mathrm{Y}$ \\
\hline Distributed lags & $\mathrm{Y}$ & $\mathrm{Y}$ & $\mathrm{Y}$ & Y \\
\hline Cross-sectional means & Y & $\mathrm{Y}$ & $\mathrm{Y}$ & $\mathrm{Y}$ \\
\hline Observations & 196,960 & 196,960 & 190,796 & 190,796 \\
\hline Number of firm bonds & 2,045 & 2,045 & 1,987 & 1,987 \\
\hline Number of countries & 46 & 46 & 31 & 31 \\
\hline R-squared (mean-group) & 0.699 & 0.808 & 0.914 & 0.913 \\
\hline
\end{tabular}

Note: This table shows the baseline estimates of model (8) using the full sample, where bond fixed effects $\left(c_{y i}\right)$, distributed lags $\left(\Delta x_{i, t-l}\right)$, and cross-sectional means $\left(\bar{y}_{t-l}\right.$ and $\left.\bar{x}_{t-l}\right)$ are not shown to save space. Control variables are defined in Table 1. In the estimation, weekly data of bond yields are matched with the most recent monthly, quarterly, and annual data of control variables. Standard errors are in parentheses, and ${ }^{* * *} \mathrm{p}<0.01,{ }^{* *} \mathrm{p}<0.05,{ }^{*} \mathrm{p}<0.1$. 
Table 3. Baseline estimates (trimmed-full sample)

\begin{tabular}{|c|c|c|c|c|}
\hline & $\begin{array}{c}(1) \\
\text { Corp. yields } \\
\end{array}$ & $\begin{array}{c}(2) \\
\text { Corp. yields }\end{array}$ & $\begin{array}{c}(3) \\
\text { Corp. yields }\end{array}$ & $\begin{array}{c}\text { (4) } \\
\text { Corp. yields }\end{array}$ \\
\hline Sovereign yields & $\begin{array}{l}0.887 * * * \\
(0.0879)\end{array}$ & $\begin{array}{c}0.833 * * * \\
(0.0535)\end{array}$ & $\begin{array}{l}0.824 * * * \\
(0.0356)\end{array}$ & $\begin{array}{l}0.824 * * * \\
(0.0356)\end{array}$ \\
\hline Average ratings & & & $\begin{array}{c}0.0243 \\
(0.0303)\end{array}$ & $\begin{array}{c}0.0243 \\
(0.0303)\end{array}$ \\
\hline Maturity & & & $\begin{array}{l}0.197 * * * \\
(0.0441)\end{array}$ & $\begin{array}{l}0.0403 \\
(0.102)\end{array}$ \\
\hline Bid-ask yield spread & & & $\begin{array}{l}-0.456 \\
(1.553)\end{array}$ & $\begin{array}{l}-0.456 \\
(1.553)\end{array}$ \\
\hline Country stock returns & & & $\begin{array}{c}8.40 \mathrm{e}-05 \\
(0.000451)\end{array}$ & $\begin{array}{c}8.40 \mathrm{e}-05 \\
(0.000451)\end{array}$ \\
\hline Country stock volatilities & & & $\begin{array}{l}0.00312 * \\
(0.00182)\end{array}$ & $\begin{array}{l}0.00312 * \\
(0.00182)\end{array}$ \\
\hline Real effective exchange rate growth & & & $\begin{array}{c}0.0112 * * * \\
(0.00231)\end{array}$ & $\begin{array}{c}0.0112 * * * \\
(0.00231)\end{array}$ \\
\hline Nominal USD exchange rate growth & & & $\begin{array}{c}0.00518 \\
(0.00424)\end{array}$ & $\begin{array}{c}0.00518 \\
(0.00424)\end{array}$ \\
\hline S\&P500 stock returns & & & $\begin{array}{c}0.000461 \\
(0.000722)\end{array}$ & $\begin{array}{c}0.000461 \\
(0.000722)\end{array}$ \\
\hline S\&P500 stock volatilities & & & $\begin{array}{c}0.00260 \\
(0.00188)\end{array}$ & $\begin{array}{c}0.00260 \\
(0.00188)\end{array}$ \\
\hline US 10-year Treasury yields & & & $\begin{array}{l}-0.0144 \\
(0.0367)\end{array}$ & $\begin{array}{l}-0.0144 \\
(0.0367)\end{array}$ \\
\hline Time trend & & $\begin{array}{c}-0.00270 * * * \\
(0.000861)\end{array}$ & & $\begin{array}{l}-0.00301 \\
(0.00195)\end{array}$ \\
\hline Bond fixed effects & $\mathrm{Y}$ & $\mathrm{Y}$ & $\mathrm{Y}$ & $\mathrm{Y}$ \\
\hline Distributed lags & $\mathrm{Y}$ & $\mathrm{Y}$ & $\mathrm{Y}$ & $\mathrm{Y}$ \\
\hline Cross-sectional means & $\mathrm{Y}$ & $\mathrm{Y}$ & Y & Y \\
\hline Observations & 178,134 & 178,134 & 177,890 & 177,890 \\
\hline Number of corporate bonds & 1,787 & 1,787 & 1,787 & 1,787 \\
\hline Number of countries & 31 & 31 & 31 & 31 \\
\hline R-squared (mean-group) & 0.751 & 0.828 & 0.926 & 0.925 \\
\hline
\end{tabular}

Note: This table is same as Table 2 except that we use the trimmed-full sample, which is obtained by trimming the full sample at the top and bottom 5 percent of corporate bonds based on the estimates of individual pass-throughs $\hat{\theta}_{i}$ from column (3) of Table 2. Standard errors are in parentheses, and ${ }^{* * *} \mathrm{p}<0.01,{ }^{* *} \mathrm{p}<0.05,{ }^{*} \mathrm{p}<0.1$. 
Table 4. Robustness

\begin{tabular}{|c|c|c|c|c|}
\hline Dependent var: Corporate bond yields & $\begin{array}{c}(1) \\
\text { MAD maturity } \\
\end{array}$ & $\begin{array}{c}(2) \\
\text { MSD maturity } \\
\end{array}$ & $\begin{array}{c}(3) \\
\text { MAD three-factor }\end{array}$ & $\begin{array}{c}(4) \\
\text { MSD three factor } \\
\end{array}$ \\
\hline Sovereign bond yields & $\begin{array}{c}0.721 * * * \\
(0.0588)\end{array}$ & $\begin{array}{l}0.721 * * * \\
(0.0588)\end{array}$ & $\begin{array}{c}0.731 * * * \\
(0.0554)\end{array}$ & $\begin{array}{c}0.751 * * * \\
(0.0552)\end{array}$ \\
\hline Observations & 151,252 & 151,197 & 148,385 & 147,093 \\
\hline Number of corporate bonds & 1,776 & 1,776 & 1,775 & 1,776 \\
\hline R-squared (mean-group) & 0.920 & 0.920 & 0.920 & 0.933 \\
\hline & $\begin{array}{c}(5) \\
\text { Extra macro controls } \\
\end{array}$ & $\begin{array}{c}(6) \\
\text { Extra firm controls } \\
\end{array}$ & $\begin{array}{c}(7) \\
\text { Drop China } \\
\end{array}$ & $\begin{array}{c}(8) \\
\text { Common-feature bonds } \\
\end{array}$ \\
\hline Sovereign bond yields & $\begin{array}{c}0.839 * * * \\
(0.0368)\end{array}$ & $\begin{array}{c}0.913 * * * \\
(0.114)\end{array}$ & $\begin{array}{l}1.059 * * * \\
(0.0473)\end{array}$ & $\begin{array}{l}0.774 * * * \\
(0.0471)\end{array}$ \\
\hline Observations & 174,538 & 37,379 & 111,351 & 124,155 \\
\hline Number of corporate bonds & 1,759 & 367 & 1,056 & 1,213 \\
\hline R-squared (mean-group) & 0.937 & 0.875 & 0.922 & 0.918 \\
\hline & $\begin{array}{c}(9) \\
\mathrm{Lag}=3 \\
\end{array}$ & $\begin{array}{c}(10) \\
\mathrm{Lag}=5 \\
\end{array}$ & $\begin{array}{c}(11) \\
\text { Panel ARDL } \\
\end{array}$ & $\begin{array}{c}(12) \\
\text { Synthetic time-series ARDL } \\
\end{array}$ \\
\hline Sovereign bond yields & $\begin{array}{l}0.770 * * * \\
(0.0386)\end{array}$ & $\begin{array}{l}0.885 * * * \\
(0.0427)\end{array}$ & $\begin{array}{c}1.011 * * * \\
(0.291)\end{array}$ & $\begin{array}{l}0.959 * * * \\
(0.0404)\end{array}$ \\
\hline Observations & 179,677 & 176,103 & 177,890 & 185,282 \\
\hline Number of corporate bonds & 1,787 & 1,787 & 1,787 & 1,787 \\
\hline R-squared (mean-group) & 0.927 & 0.926 & 0.433 & 0.134 \\
\hline
\end{tabular}


Table 5. Subsample estimates (transfer risks)

\begin{tabular}{|c|c|c|c|c|}
\hline Dependent var: & (1) & $(2)$ & (3) & (4) \\
\hline Corporate bond yields & IG countries & Non-IG countries & Low debt/reserves & High debt/reserves \\
\hline \multirow[t]{2}{*}{ Sovereign bond yields } & $0.591 * * *$ & $1.078 * * *$ & $0.614 * * *$ & $1.296^{* * *}$ \\
\hline & $(0.0984)$ & $(0.0632)$ & $(0.0604)$ & $(0.0989)$ \\
\hline Observations & 121,433 & 56,457 & 133,097 & 44,793 \\
\hline Number of corporate bonds & 1,218 & 569 & 1,348 & 439 \\
\hline \multirow[t]{3}{*}{ R-squared (mean-group) } & 0.902 & 0.954 & 0.919 & 0.938 \\
\hline & $(5)$ & $(6)$ & $(7)$ & $(8)$ \\
\hline & Financial bonds & Non-financial bonds & Government-related bonds & Non-related bonds \\
\hline \multirow[t]{2}{*}{ Sovereign bond yields } & $1.197 * * *$ & $0.678^{* * *}$ & $0.474 * * *$ & $0.882 * * *$ \\
\hline & $(0.0980)$ & $(0.0421)$ & $(0.0470)$ & $(0.0463)$ \\
\hline Observations & 63,705 & 114,185 & 68,044 & 109,846 \\
\hline Number of corporate bonds & 688 & 1,099 & 638 & 1,149 \\
\hline \multirow[t]{3}{*}{ R-squared (mean-group) } & 0.947 & 0.916 & 0.841 & 0.937 \\
\hline & $(9)$ & $(10)$ & $(11)$ & $(12)$ \\
\hline & Financial govern-related & Financial non-related & Non-financial govern-related & Non-financial non-relatec \\
\hline \multirow[t]{2}{*}{ Sovereign bond yields } & 0.103 & $1.270 * * *$ & $0.665 * * *$ & $0.577 * * *$ \\
\hline & $(0.107)$ & $(0.111)$ & $(0.0542)$ & $(0.0614)$ \\
\hline Observations & 23,040 & 40,665 & 45,004 & 69,181 \\
\hline Number of corporate bonds & 241 & 447 & 397 & 702 \\
\hline \multirow[t]{3}{*}{ R-squared (mean-group) } & 0.958 & 0.946 & 0.776 & 0.933 \\
\hline & $(13)$ & $(14)$ & $(15)$ & $(16)$ \\
\hline & Column (9) drop China & Column (10) drop China & Column (11) drop China & Column (12) drop China \\
\hline \multirow[t]{2}{*}{ Sovereign bond yields } & $0.999 * * *$ & $1.441^{* * *}$ & $1.127 * * *$ & $0.789^{* * *}$ \\
\hline & $(0.191)$ & $(0.125)$ & $(0.0984)$ & $(0.0628)$ \\
\hline Observations & 5,607 & 23,375 & 29,298 & 53,071 \\
\hline Number of corporate bonds & 57 & 236 & 253 & 510 \\
\hline R-squared (mean-group) & 0.970 & 0.947 & 0.794 & 0.931 \\
\hline
\end{tabular}

Note: This table shows the mean-group estimates of the long-run sovereign-to-corporate pass-through for 16 different subsamples; see section 5.1 for discussions of these cases. All columns follow the specification in column (3) of Table 3; control variables, bond fixed effects, distributed lags, and cross-sectional means are included but their coefficients are not reported to save space (available upon request). Standard errors are in parentheses, and $* * * \mathrm{p}<0.01, * * \mathrm{p}<0.05,{ }^{*} \mathrm{p}<0.1$. 
Table 6. Subsample estimates (linkage through liquidity premiums)

Dependent var: Corporate bond yields

(1)

IG \& LBA countries

\begin{tabular}{lcc}
\hline \hline Sovereign bond yields & $0.496^{* * *}$ & -0.965 \\
& $(0.182)$ & $(0.643)$ \\
Observations & 50,007 & 71,426 \\
Number of corporate bonds & 442 & 776 \\
R-squared (mean-group) & 0.832 & 0.955 \\
\hline Dependent var: Corporate bond yields & $(3)$ & $(4)$ \\
& Non-IG \& LBA countries & Non-IG \& HBA countries \\
\hline \hline Sovereign bond yields & $1.411^{* * *}$ & $1.181^{* * *}$ \\
& $(0.164)$ & $(0.0945)$ \\
Observations & 22,659 & 33,798 \\
Number of corporate bonds & 226 & 343 \\
R-squared (mean-group) & 0.950 & 0.955 \\
\hline
\end{tabular}

Note: This table shows the mean-group estimates of the long-run sovereign-to-corporate pass-through for 4 different subsamples, based on a country's sovereign ratings and the bid-ask yield spreads of sovereign bonds; see section 5.2 for discussions of these cases. All columns follow the specification in column (3) of Table 3; control variables, bond fixed effects, distributed lags, and cross-sectional means are included but their coefficients are not reported to save space (available upon request). Standard errors are in parentheses, and ${ }^{* * *} \mathrm{p}<0.01,{ }^{* *} \mathrm{p}<0.05,{ }^{*} \mathrm{p}<0.1$. 
Table 7. Subsample estimates (corporate bonds' ratings and maturities)

Dependent var: Corporate bond yields

(1)

(2)

IG corporate bonds

Non-IG corporate bonds

\begin{tabular}{lc}
\hline \hline Sovereign bond yields & $0.548^{* * *}$ \\
& $(0.0546)$ \\
Observations & 92,196 \\
Number of corporate bonds & 852 \\
R-squared (mean-group) & 0.941 \\
\hline Dependent var: Corporate bond yields & $(3)$ \\
& ST corporate bonds \\
\hline \hline Sovereign bond yields & $0.935^{* * *}$ \\
& $(0.0574)$ \\
Observations & 100,526 \\
Number of corporate bonds & 1,087 \\
R-squared (mean-group) & 0.952 \\
\hline Dependent var: Corporate bond yields & $(5)$ \\
& LT corporate bonds \\
\hline \hline Sovereign bond yields & $0.488^{* * *}$ \\
& $(0.0825)$ \\
Observations & 22,911 \\
Number of corporate bonds & 189 \\
R-squared (mean-group) & 0.922 \\
\hline
\end{tabular}

Note: This table shows the mean-group estimates of the long-run sovereign-to-corporate pass-through for 5 different subsamples, based on corporate bonds' ratings and maturities; see section 5.3 for discussions of these cases. All columns follow the specification in column (3) of Table 3; control variables, bond fixed effects, distributed lags, and cross-sectional means are included but their coefficients are not reported to save space (available upon request). Standard errors are in parentheses, and $* * * \mathrm{p}<0.01, * * \mathrm{p}<0.05, * \mathrm{p}<0.1$. 
Table 8. Nonlinearity

\begin{tabular}{|c|c|c|c|c|}
\hline & $\begin{array}{c}\text { (1) } \\
\text { Corp. yields }\end{array}$ & $\begin{array}{c}\text { (2) } \\
\text { Corp. yields }\end{array}$ & $\begin{array}{c}\text { (3) } \\
\text { Corp. yields }\end{array}$ & $\begin{array}{c}\text { (4) } \\
\text { Corp. yields }\end{array}$ \\
\hline Sovereign yields & $\begin{array}{c}0.887 * * * \\
(0.0879)\end{array}$ & $\begin{array}{c}-2.975^{* * *} \\
(0.969)\end{array}$ & $\begin{array}{c}0.824 * * * \\
(0.0356)\end{array}$ & $\begin{array}{c}0.541 \\
(1.784)\end{array}$ \\
\hline Sovereign yields squared & & $\begin{array}{c}0.478 * * * \\
(0.114)\end{array}$ & & $\begin{array}{l}0.0113 \\
(0.220)\end{array}$ \\
\hline Average ratings & & & $\begin{array}{c}0.0243 \\
(0.0303)\end{array}$ & $\begin{array}{l}-93.51 \\
(120.0)\end{array}$ \\
\hline Maturity & & & $\begin{array}{c}0.197 * * * \\
(0.0441)\end{array}$ & $\begin{array}{r}-0.0900 \\
(0.172)\end{array}$ \\
\hline Bid-ask yield spread & & & $\begin{array}{c}-0.456 \\
(1.553)\end{array}$ & $\begin{array}{c}10,335 \\
(13,124)\end{array}$ \\
\hline Country stock returns & & & $\begin{array}{c}8.40 \mathrm{e}-05 \\
(0.000451)\end{array}$ & $\begin{array}{l}-0.00163 \\
(0.00110)\end{array}$ \\
\hline Country stock volatilities & & & $\begin{array}{l}0.00312 * \\
(0.00182)\end{array}$ & $\begin{array}{c}0.00557 \\
(0.00358)\end{array}$ \\
\hline Real effective exchange rate growth & & & $\begin{array}{c}0.0112 * * * \\
(0.00231)\end{array}$ & $\begin{array}{c}0.00613 \\
(0.00436)\end{array}$ \\
\hline Nominal USD exchange rate growth & & & $\begin{array}{c}0.00518 \\
(0.00424)\end{array}$ & $\begin{array}{c}0.00377 \\
(0.00509)\end{array}$ \\
\hline S\&P500 stock returns & & & $\begin{array}{c}0.000461 \\
(0.000722)\end{array}$ & $\begin{array}{c}0.00124 \\
(0.00163)\end{array}$ \\
\hline S\&P500 stock volatilities & & & $\begin{array}{c}0.00260 \\
(0.00188)\end{array}$ & $\begin{array}{c}0.00172 \\
(0.00254)\end{array}$ \\
\hline US 10-year Treasury yields & & & $\begin{array}{l}-0.0144 \\
(0.0367)\end{array}$ & $\begin{array}{l}-0.0737 \\
(0.0508)\end{array}$ \\
\hline Bond fixed effects & $\mathrm{Y}$ & Y & $\mathrm{Y}$ & Y \\
\hline Distributed lags & Y & Y & Y & Y \\
\hline Cross-sectional means & $\mathrm{Y}$ & $\mathrm{Y}$ & $\mathrm{Y}$ & $\mathrm{Y}$ \\
\hline Observations & 178,134 & 178,134 & 177,890 & 177,890 \\
\hline Number of corporate bonds & 1,787 & 1,787 & 1,787 & 1,787 \\
\hline R-squared (mean-group) & 0.751 & 0.813 & 0.926 & 0.941 \\
\hline
\end{tabular}

Note: Columns (1) and (3) of this table are same as those in Table 3. In contrast, we include the squared term of sovereign yields in columns (2) and (4) to capture potential nonlinear effects; see section 6.2 for discussions. Standard errors are in parentheses, and ${ }^{* * *} \mathrm{p}<0.01, * * \mathrm{p}<0.05, * \mathrm{p}<0.1$. 


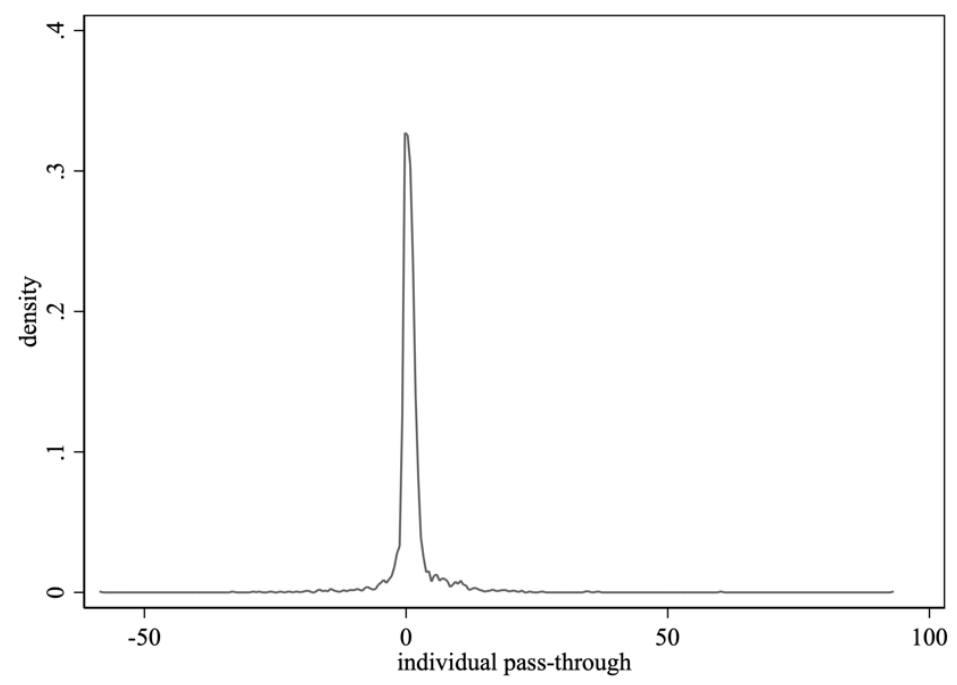

Figure 1. Individual pass-throughs of the full-sample baseline estimates

Note: This figure shows the Epanechnikov kernel density of the estimated individual pass-throughs $\widehat{\theta}_{i}$ for column (3) of Table 2. Mean $=0.951 ;$ median $=0.595 ;$ standard deviation $=4.959$.

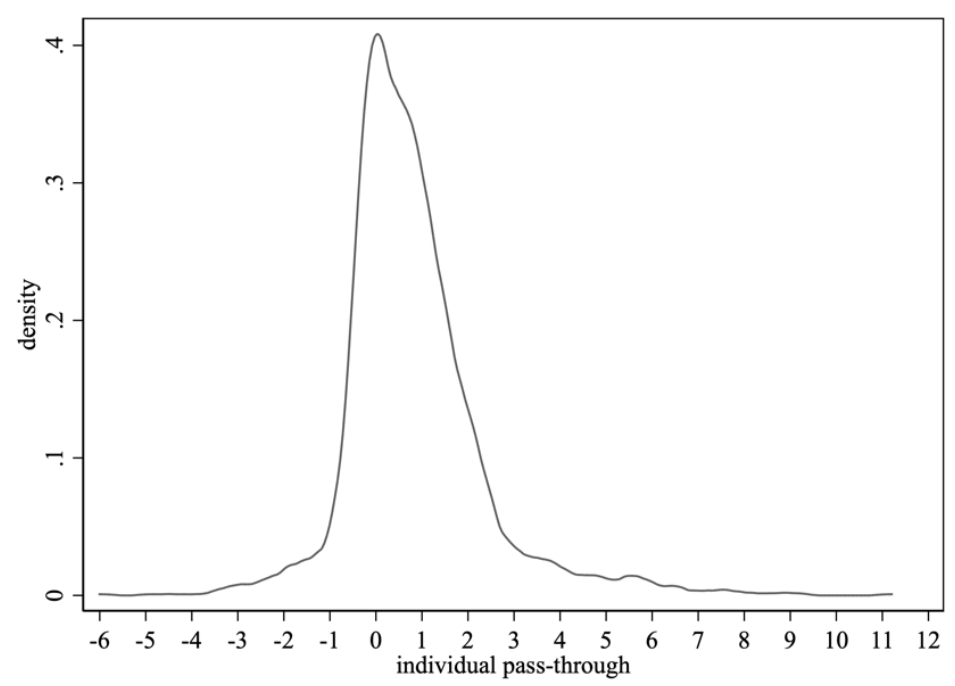

Figure 2. Individual pass-throughs of the trimmed-full-sample baseline estimates

Note: This figure shows the Epanechnikov kernel density of the estimated individual pass-throughs $\hat{\theta}_{i}$ for column (3) of Table 3. Mean $=0.824$; median $=0.581$; standard deviation $=1.506$. 


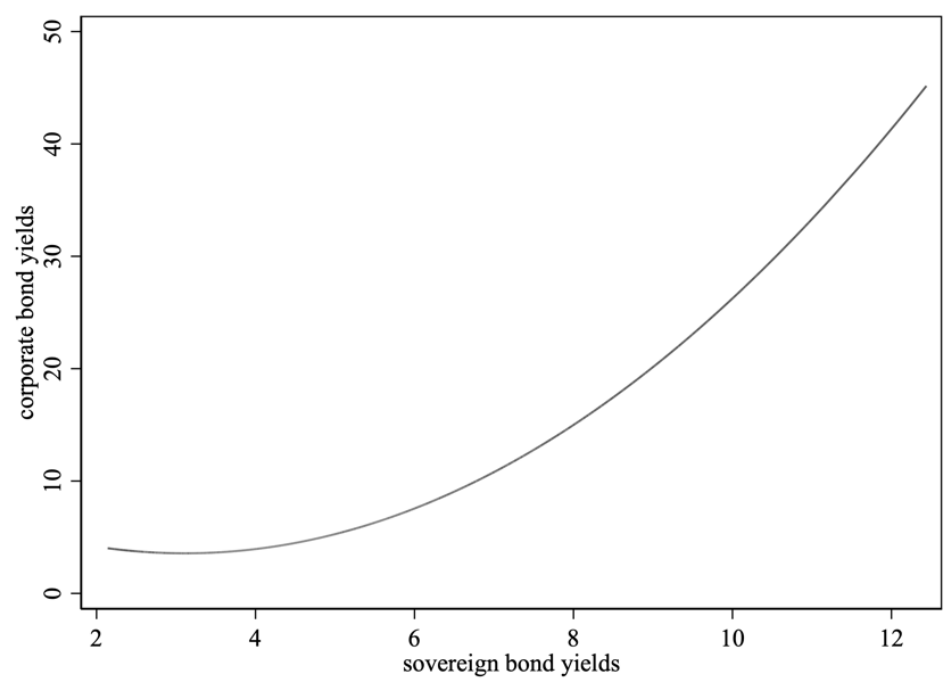

Figure 3. Fitted nonlinear effects (column 2 of Table 8)

Note: This figure shows the fitted relation between corporate yields $(\mathrm{y})$ and sovereign yields (x) using the estimates in column (2) of Table 8 . The curve is: $\hat{y}=-2.975 x+0.478 x^{2}+8.199$, where the number 8.199 is the estimated constant (i.e., the mean-group estimate of the bond fixed effect). 


\section{APPENDIX}

\section{A1. Panel cointegration tests}

\begin{tabular}{lccccc}
\hline & Lag=1 & Lag=2 & Lag=3 & Lag=4 & Lag=5 \\
\hline \hline Modified Phillips-Perron test & 0.00 & 0.00 & 0.00 & 0.00 & 0.00 \\
Modified Dickey-Fuller test & 0.00 & 0.00 & 0.00 & 0.00 & 0.00 \\
Dickey-Fuller test & 0.00 & 0.00 & 0.00 & 0.00 & 0.00 \\
\hline
\end{tabular}

This table shows the $p$-values of three different panel-data cointegration tests toward our sample, where the dependent variable is individual corporate bond yields, and the independent variable is the average sovereign bond yields of the same country. The cross-sectional size of the panel is 2,045, which corresponds to the number of individual corporate bonds, and for each bond, the time-series length is at least 30 weeks and at most 160 weeks. The modified Phillips-Perron test is developed in Pedroni (1999, 2004), and the modified Dickey-Fuller test and the DickeyFuller test are from Kao (1999). All tests have a common null hypothesis of no cointegration and a common alternative hypothesis that the variables are cointegrated for all panel individuals. All tests include individual fixed effects and are robust to potential cross-sectional dependence, endogeneity, and irrespective of whether or not a deterministic trend is included. We show the test results for the number of lags from 1 to 5 (weeks) here, but the results are also robust to using information criteria (AIC, BIC or HQIC) to select the optimal number of lags within this range. The maximum number of lags 5 is determined by the integer part of the cube root of the maximum time-series length: i.e., $[\sqrt[3]{160}]$, following Chudik, Mohaddes, Pesaran, and Raissi (2017).

\section{A2. List of countries and numbers of bonds}

\begin{tabular}{l|c|ccc}
\hline Country of risk & Sovereign & Corporate & Government-related & Non-related \\
\hline \hline Argentina & 34 & 44 & 8 & 36 \\
Armenia & 2 & 1 & 0 & 1 \\
Azerbaijan & 4 & 2 & 2 & 0 \\
Bahrain & 8 & 5 & 3 & 2 \\
Belarus & 3 & 1 & 0 & 1 \\
Brazil & 15 & 191 & 35 & 156 \\
Chile & 7 & 107 & 25 & 82 \\
China & 4 & 862 & 335 & 527 \\
Colombia & 13 & 41 & 10 & 31 \\
Congo (Democratic Republic) & 1 & 1 & 0 & 1 \\
Costa Rica & 29 & 2 & 1 & 1 \\
Croatia & 3 & 2 & 2 & 0 \\
Dominican Republic & 14 & 5 & 1 & 4 \\
Ecuador & 9 & 2 & 2 & 2 \\
Georgia & 1 & 4 & 2 &
\end{tabular}




\begin{tabular}{|c|c|c|c|c|}
\hline Ghana & 8 & 6 & 0 & 6 \\
\hline Guatemala & 5 & 9 & 0 & 9 \\
\hline Honduras & 3 & 1 & 0 & 1 \\
\hline Hungary & 5 & 3 & 1 & 2 \\
\hline Indonesia & 26 & 81 & 24 & 57 \\
\hline Jamaica & 8 & 5 & 0 & 5 \\
\hline Jordan & 10 & 1 & 0 & 1 \\
\hline Kazakhstan & 2 & 24 & 13 & 11 \\
\hline Kuwait & 2 & 10 & 3 & 7 \\
\hline Lebanon & 23 & 1 & 0 & 1 \\
\hline Mexico & 18 & 210 & 88 & 122 \\
\hline Mongolia & 4 & 1 & 1 & 0 \\
\hline Morocco & 2 & 4 & 3 & 1 \\
\hline Nigeria & 8 & 15 & 0 & 15 \\
\hline Oman & 8 & 10 & 5 & 5 \\
\hline Panama & 18 & 14 & 4 & 10 \\
\hline Paraguay & 6 & 3 & 0 & 3 \\
\hline Peru & 5 & 59 & 1 & 58 \\
\hline Philippines & 16 & 22 & 0 & 22 \\
\hline Poland & 6 & 2 & 0 & 2 \\
\hline Qatar & 10 & 28 & 18 & 10 \\
\hline Russian Federation & 10 & 119 & 36 & 83 \\
\hline Saudi Arabia & 9 & 11 & 8 & 3 \\
\hline South Africa & 12 & 38 & 6 & 32 \\
\hline Sri Lanka & 13 & 4 & 3 & 1 \\
\hline Trinidad and Tobago & 3 & 5 & 5 & 0 \\
\hline Turkey & 21 & 63 & 11 & 52 \\
\hline Ukraine & 9 & 15 & 4 & 11 \\
\hline Uruguay & 10 & 2 & 0 & 2 \\
\hline Vietnam & 1 & 1 & 1 & 0 \\
\hline Zambia & 3 & 8 & 0 & 8 \\
\hline Total & 431 & 2045 & 1384 & 661 \\
\hline
\end{tabular}

This table shows the list of countries that our sample include and the number of bonds in each country. Countries that are in bold fonts are those with MSCI stock-market data available to us. We show the number of sovereign bonds and the number of corporate bonds (and which of the latter are government-related corporate bonds and non-government-related corporate bonds, respectively). 


\section{A3. Phillips-Perron unit-root tests for individual bonds}

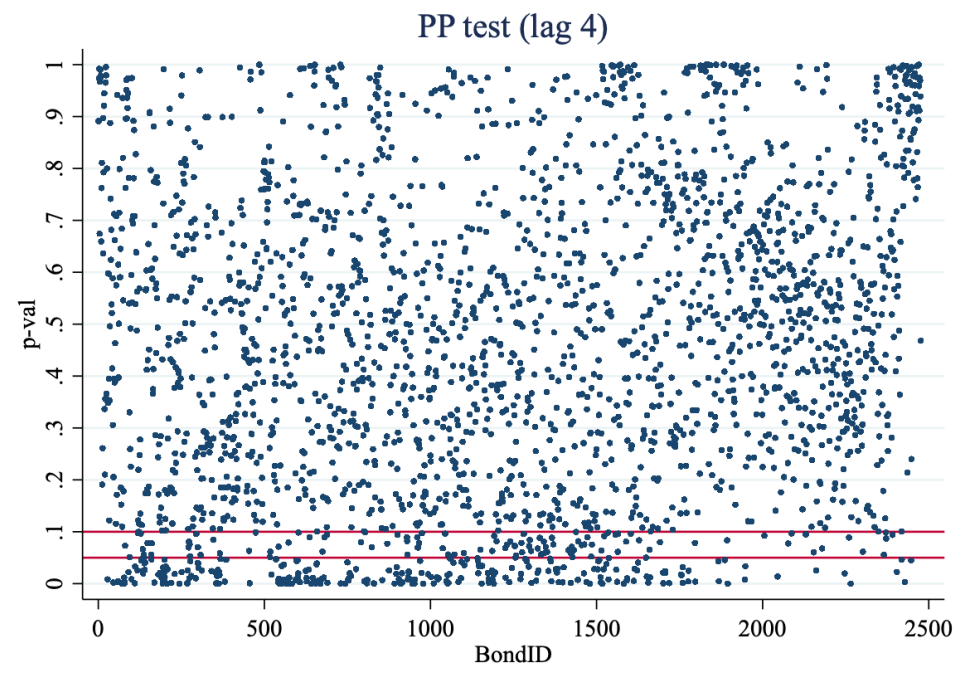

This figure shows the p-values of the Phillips-Perron unit-root test for each individual bond in our sample, where each dot represents a bond, and the number of lags is 4 (weeks). The red lines represent 0.05 and 0.1 , below which the null hypothesis of unit roots is rejected. The test results show that a majority of bonds contain unit roots. This conclusion is robust to the number of lags being 3 or 5 instead and irrespective of whether or not a trend term is included. 


\section{A4. Robustness of including more control variables}

\begin{tabular}{|c|c|c|c|}
\hline $\begin{array}{l}\text { Dependent var: } \\
\text { Corporate bond yields }\end{array}$ & $\begin{array}{c}\text { (1) } \\
\text { monthly dummies } \\
\end{array}$ & $\begin{array}{c}(2) \\
\text { excess bond premium } \\
\end{array}$ & $\begin{array}{c}(3) \\
\text { portfolio investment (net) / GDP } \\
\end{array}$ \\
\hline Sovereign bond yields & $\begin{array}{l}0.906 * * * \\
(0.0536)\end{array}$ & $\begin{array}{l}0.798 * * * \\
(0.0369)\end{array}$ & $\begin{array}{l}0.861 * * * \\
(0.0373)\end{array}$ \\
\hline Observations & 177,890 & 177,890 & 176,757 \\
\hline Number of corporate bonds & 1,787 & 1,787 & 1,773 \\
\hline R-squared (mean-group) & 0.97 & 0.930 & 0.929 \\
\hline & $\begin{array}{c}\text { (4) } \\
\text { portfolio investment (assets) / GDP }\end{array}$ & $\begin{array}{c}(5) \\
\text { portfolio investment (liabilities) / GDP }\end{array}$ & $\begin{array}{c}\text { (6) } \\
\text { Moody's U.S. Aaa yields } \\
\end{array}$ \\
\hline Sovereign bond yields & $\begin{array}{l}0.872 * * * \\
(0.0376)\end{array}$ & $\begin{array}{l}0.858 * * * \\
(0.0379)\end{array}$ & $\begin{array}{l}0.855^{* * *} \\
(0.0387)\end{array}$ \\
\hline Observations & 176,433 & 176,757 & 177,890 \\
\hline Number of corporate bonds & 1,769 & 1,773 & 1,787 \\
\hline R-squared (mean-group) & 0.930 & 0.929 & 0.929 \\
\hline & $\begin{array}{c}\text { (7) } \\
\text { Moody's U.S. Baa yields } \\
\end{array}$ & $\begin{array}{l}\text { (8) } \\
\text { oil price growth } \\
\end{array}$ & $\begin{array}{c}(9) \\
\text { all variables (2)-(8) } \\
\end{array}$ \\
\hline Sovereign bond yields & $\begin{array}{l}0.736 * * * \\
(0.0394)\end{array}$ & $\begin{array}{l}0.832 * * * \\
(0.0364)\end{array}$ & $\begin{array}{l}0.949 * * * \\
(0.152)\end{array}$ \\
\hline Observations & 177,890 & 177,890 & 176,433 \\
\hline Number of corporate bonds & 1,787 & 1,787 & 1,769 \\
\hline R-squared (mean-group) & 0.931 & 0.926 & 0.941 \\
\hline
\end{tabular}

This table shows estimation results of including additional control variables (suggested by the title of each column) based on the model in Table 3, column (3). See section 4.2, footnote 29 for details. Excess bond premium is from Gilchrist and Zakrajsek (2012). Portfolio investment flows are obtained from IMF internal databases. Moody's U.S. Aaa and Baa index yields are from FRED. Oil price growth is calculated as the weekly growth rate of oil price index, which is the average of three spot prices_-Dated Brent, West Texas Intermediate, and the Dubai Fateh—obtained from IMF internal databases. Standard errors are in parentheses, and $* * * \mathrm{p}<0.01,{ }^{* *} \mathrm{p}<0.05,{ }^{*} \mathrm{p}<0.1$. 
A5. Robustness of credit spreads

\begin{tabular}{|c|c|c|}
\hline & $\begin{array}{c}(1) \\
\text { Corp. yields } \\
\end{array}$ & $\begin{array}{c}(2) \\
\text { Corp. spreads }\end{array}$ \\
\hline Sovereign yields & $\begin{array}{c}0.824 * * * \\
(0.0356)\end{array}$ & \\
\hline Sovereign spreads & & $\begin{array}{c}0.831 * * * \\
(0.156)\end{array}$ \\
\hline Average ratings & $\begin{array}{c}0.0243 \\
(0.0303)\end{array}$ & $\begin{array}{c}-0.00451 \\
(0.0321)\end{array}$ \\
\hline Maturity & $\begin{array}{c}0.197 * * * \\
(0.0441)\end{array}$ & $\begin{array}{c}0.326^{* * *} \\
(0.0792)\end{array}$ \\
\hline Bid-ask yield spread & $\begin{array}{l}-0.456 \\
(1.553)\end{array}$ & $\begin{array}{l}0.0935 \\
(0.950)\end{array}$ \\
\hline Country stock returns & $\begin{array}{c}8.40 \mathrm{e}-05 \\
(0.000451)\end{array}$ & $\begin{array}{l}-0.00152 * * \\
(0.000608)\end{array}$ \\
\hline Country stock volatilities & $\begin{array}{l}0.00312 * \\
(0.00182)\end{array}$ & $\begin{array}{l}0.00627^{*} \\
(0.00330)\end{array}$ \\
\hline Real effective exchange rate growth & $\begin{array}{c}0.0112 * * * \\
(0.00231)\end{array}$ & $\begin{array}{l}0.00638^{*} \\
(0.00369)\end{array}$ \\
\hline Nominal USD exchange rate growth & $\begin{array}{c}0.00518 \\
(0.00424)\end{array}$ & $\begin{array}{l}-0.00414 \\
(0.00614)\end{array}$ \\
\hline S\&P500 stock returns & $\begin{array}{c}0.000461 \\
(0.000722)\end{array}$ & $\begin{array}{l}-0.000833 \\
(0.000790)\end{array}$ \\
\hline S\&P500 stock volatilities & $\begin{array}{c}0.00260 \\
(0.00188)\end{array}$ & $\begin{array}{c}0.00680^{* * *} \\
(0.00238)\end{array}$ \\
\hline US 10-year Treasury yields & $\begin{array}{l}-0.0144 \\
(0.0367)\end{array}$ & $\begin{array}{c}-0.123 * * * \\
(0.0198)\end{array}$ \\
\hline Bond fixed effects & $\mathrm{Y}$ & Y \\
\hline Distributed lags & $\mathrm{Y}$ & $\mathrm{Y}$ \\
\hline Cross-sectional means & Y & Y \\
\hline Observations & 177,890 & 147,729 \\
\hline Number of corporate bonds & 1,787 & 1,744 \\
\hline R-squared (mean-group) & 0.926 & 0.937 \\
\hline
\end{tabular}

This table compares the estimation results of bond yields, i.e., our baseline estimates, to those of bond credit spreads. See discussions in section 4.2. The credit spreads are Z spreads, and the data are from IHS Markit (for corporate bonds) and Bloomberg (for sovereign bonds), where the benchmark securities are selected by the corresponding data provider. Standard errors are in parentheses, and $* * * p<0.01, * * p<0.05$, $* \mathrm{p}<0.1$ 